Article

\title{
Social Sustainability in Fashion Supply Chains- Understanding Social Standard Implementation Failures in Vietnam and Indonesia Using Agency Theory
}

\author{
Deniz Köksal *(D) and Jochen Strähle $\mathbb{1}$ \\ School of Textiles and Design, Reutlingen University, Alteburgstraße 150, 72762 Reutlingen, Germany; \\ jochen.straehle@reutlingen-university.de \\ * Correspondence: deniz.koeksal@reutlingen-university.de
}

Citation: Köksal, D.; Strähle, J. Social Sustainability in Fashion Supply

Chains-Understanding Social

Standard Implementation Failures in Vietnam and Indonesia Using Agency Theory. Sustainability 2021, 13, 2159. https://doi.org/10.3390/su13042159

Academic Editors: Mohammad Nurunnabi and Marc A. Rosen

Received: 2 January 2021

Accepted: 10 February 2021

Published: 17 February 2021

Publisher's Note: MDPI stays neutral with regard to jurisdictional claims in published maps and institutional affiliations.

Copyright: (c) 2021 by the authors. Licensee MDPI, Basel, Switzerland. This article is an open access article distributed under the terms and conditions of the Creative Commons Attribution (CC BY) license (https:// creativecommons.org/licenses/by/ $4.0 /)$.

\begin{abstract}
This paper explores why and how dominant international social standards used in the fashion industry are prone to implementation failures. A qualitative multiple-case study method was conducted, using purposive sampling to select 13 apparel supply chain actors. Data were collected through on-site semi-structured face-to-face interviews. The findings of the study are interpreted by using core tenets of agency theory. The case study findings clearly highlight why and how multi-tier apparel supply chains fail to implement social standards effectively. As a consequence of substantial goal conflicts and information asymmetries, sourcing agents and suppliers are driven to perform opportunistic behaviors in form of hidden characteristics, hidden intentions, and hidden actions, which significantly harm social standards. Fashion retailers need to empower their corporate social responsibility (CSR) departments by awarding an integrative role to sourcing decisions. Moreover, accurate calculation of orders, risk sharing, cost sharing, price premiums, and especially guaranteed order continuity for social compliance are critical to reduce opportunistic behaviors upstream of the supply chain. The development of social standards is highly suggested, e.g., by including novel metrics such as the assessment of buying practices or the evaluation of capacity planning at factories and the strict inclusion of subcontractors' social performances. This paper presents evidence from multiple Vietnamese and Indonesian cases involving sourcing agents as well as Tier 1 and Tier 2 suppliers on a highly sensitive topic. With the development of the conceptual framework and the formulation of seven related novel propositions, this paper unveils the ineffectiveness of social standards, offers guidance for practitioners, and contributes to the neglected social dimension in sustainable supply chain management research and accountability literature.
\end{abstract}

Keywords: social sustainability; social standards; fashion/apparel industry; SSCM; developing countries

\section{Introduction}

Retailers are held increasingly accountable for the social impact of their production activities [1,2], and the imperative to implement SSCM (sustainable supply chain management) related compliance practices is vital to reduce social risks in the supply chain [3-5]. One predominantly discussed compliance practice is the widespread adoption and use of international social accountability standards [6,7], which aim to set social sustainability guidelines for the respective supply chain partners in order to mitigate social risks through auditing and monitoring mechanisms [3,8]. In fact, given the globally fragmented, complex, and dynamic supply chain structure in the apparel industry and the enormous price and lead time pressures, significant problems arise in managing social issues in multi-tier supply chains through social standards [9-12]. Although the garment sector widely accepted the use of private social standards such as BSCI (Business Social Compliance Initiative), WRAP (Worldwide Responsible Accredited Production), and SA8000 (Social Accountability 8000 Standard) [13], which may increase legitimacy and credibility to stakeholders, it has 
been criticized for its improvements of the working conditions, especially for upstream supply chain actors in developing countries [10,14-17].

For example, two of the five factories of the Rana Plaza incident, which killed over 1134 people and injured thousands more, were audited a few months earlier by independent auditing companies on the basis of BSCI [18]. Another tragic example is the fire in a Pakistani garment factory in 2012 that killed around 300 people due to locked emergency exits and blocked windows, although the factory passed an independent third-party audit for SA8000 certification few weeks earlier $[19,20]$. These incidents as well as the massive reports on sweatshop conditions in the apparel industry raise many reasonable doubts about the nature and effectiveness of social standards [6,21-24]. In this respect, previous research proposes that social standard implementation failures might be caused by opportunistic behaviors in supply chains, usually driving supply chain actors to violate standards $[25,26]$. However, evidence from a real-life context is scarce. Nevertheless, there is an urgent need for the exploration of social standard implementation on the spot, which includes the views and behaviors of developing country suppliers in multi-tier supplier chain settings [27-30]. The following research question will help to uncover why opportunistic behaviors are performed in multi-tier apparel supply chains, which are leading to significant social standard implementation failures.

$R Q:$ Why are apparel sourcing agents and suppliers prone to opportunistic behaviors and how do these behaviors impede the effectiveness of social standard implementation in multi-tier supply chains?

Accordingly, critical research gaps are addressed. First, this study contributes to the neglected social dimension in SSCM related research [5,31,32]. Based on evidence from developing country suppliers, this study further provides a rich understanding of why the implementation of social standards in multi-tier supply chain settings are defective, addressing a serious shortfall [5,29,31,33-35]. Further, the adoption of agency theory tenets to identify opportunistic behaviors of apparel sourcing agents and suppliers is limited, however useful for uncovering social standard failures from an organizational relationship perspective $[17,29,32,36,37]$. Drawing on agency theory, this study aims to develop a conceptual map and formulate novel propositions that inform apparel supply chain actors of why and how their behaviors lead to social standard implementation failures [5].

The next section presents the theoretical background of the study and proposes the guiding theoretical framework. The main components of the theoretical framework will be explained and justified by linking agency theory to social standard implementation in multi-tier supply chains. Section 3 outlines the research design and respective methodology. Section 4 reports on the cross-case findings. Section 5 discusses the findings, outlines novel propositions, and develops a conceptual map useful for the SSCM and social accountability debate. Lastly, this paper ends with conclusions, managerial implications, and further research avenues.

\section{Theoretical Background}

In order to manage social issues in supply chains, retailers can apply three major responsible supply chain actions, i.e., compliance, supplier development, and communication practices [5]. In this regard, former studies of the SSCM stream discuss compliance practices through standards, audits, and monitoring as vital capabilities for the management of social risks, stakeholder pressures, and the improvement of social performance in the supply chain $[29,31,38-40]$. As Turker and Altuntas [8] summarize, "compliance, monitoring, and auditing are the main component of current SSCM to avoid risks, improve supply chain performance, and set clear criteria for suppliers". Researchers stress the scarce evidence on the dissemination of these compliance practices throughout the entire supply chain, especially how upstream suppliers are affected by the buyer's social standard requirements and how these requirements are passed on to first-tier and lower-tier suppliers $[27,28,41,42]$. Despite the growing interest in analyzing management practices in multi-tier supply chains, Tachizawa and Wong [33] emphasize the importance of in- 
vestigating the context under which management practices, such as compliance practices, may be effective. This raises the question about the conditions social standards are exposed to, assuming that multi-tier supply chains are governed by substantial goal conflicts and information asymmetries $[25,34,43]$.

In accordance with the goal of this paper, the author focuses solely on compliance practices that suggest the use of (private) social standards and respective social auditing and monitoring activities $[5,8]$. Therefore, it is important to note that BSCI, WRAP, and SA8000 have been selected for this study, because they are predominantly used in the apparel industry [44-47]. Ultimately, this work can be settled confidently within the field of SSCM [40,48] and contributes to sustainability accountability research [1,7].

\subsection{Social Standards in Multi-Tier Apparel Supply Chains}

Besides the traditional order winning criteria such as price, lead time, capacity, quality, and technical requirements, apparel retailers usually insist on social standard certification in order to communicate social accountability to stakeholders and manage (mitigate) social risks in their supply chains $[7,49,50]$. Typically, apparel retailers require compliance with BSCI, WRAP, and SA8000 from their upstream supply chain partners [13,45]. In short, while SA8000 is multi-stakeholder initiated (MSI), WRAP and BSCI are business driven initiatives, i.e., initiated by industry associations (IA). In this respect, SA8000 and WRAP involve accreditation systems (certification), whereas BSCI suggests a common code of conduct that is initiated by a group of companies and requires social audit and report systems. All three social standards refer to the production sites (suppliers), are basically informed by ILO (International Labor Organization)conventions; share similarities in their codes regarding, e.g., child labor, harassment and abuse, non-discrimination, forced labor, wages and benefits, working hours, disciplinary practices, and the right to freedom of association, health, and safety; and require social audits and monitoring [16,45,51,52]. To that effect, BSCI, WRAP, and SA8000 suggest accredited third-party auditing companies to audit, monitor, and verify compliance of a supplier against the respective codes $[7,17,53]$.

In order to disseminate social standards and coordinate their implementation in a multi-tier supply chain setting, literature suggest the "indirect" supplier management practice [33]. This approach is based on Mena et al.'s [54] "open" structure in multi-tier supply chains, in which information and products flow in a linear fashion, i.e., from second-tier supplier to first-tier supplier, and from first-tier supplier finally to the buyer. Here the buyers are in no direct relationship with lower-tier suppliers and thus exert pressure and expect their first-tier suppliers to ensure social standard implementation and effectiveness further upstream in the supply chain $[27,41]$. Accordingly, first-tier suppliers assume a double agency role, since they are not only asked to ensure social standard implementation in its own operations (i.e., primary agency role), but also take over the responsibility to diffuse and pass through social standards to lower-tier suppliers and ensure compliance (i.e., secondary agency role) [34,55]. In fact, social standards such as BSCI, WRAP, and SA8000 dictate the first-tier supplier's responsibility to monitor and assess their direct lower-tier suppliers, i.e., second-tier suppliers against the respective principles of the standard [56]. Hence, by requiring a certain social standard, buyers simply pass on responsibility and rely on their first-tier suppliers to manage their lower-tier suppliers. However, researchers criticize the fact that the buyer's perspective and their first-tier supplier relationship has been investigated predominantly, while there is little known about how (lower-tier) suppliers perceive the social compliance strategies of their buyers $[27,28]$. Moreover, the sourcing agent as an intermediary between the buyer and the first-tier supplier has been neglected widely in multi-tier supply chain research, although researchers found that a sourcing agent assumes high responsibility for managing and ensuring the implementation of required social standards further upstream in the supply chain [57]. However, it remains unclear how social standard implementation will be diffused and implemented in "indirect" multi-tier supply chain structures considering another additional supply chain actor, i.e., the sourcing agent as a mediator [11,58,59]. 
As the explanatory power of agency theory has been considered to be highly useful to interpret global supply chain relations [25], this study investigates how upstream supply chain behaviors might affect the implementation of required social standards [33].

\subsection{Agency Theory}

Agency theory intends to study relationships "in which one party (acting as principal) delegates work to another party (the agent), who performs the work" [60]. In an agency relationship, the contract is of core interest, which determines that the agent performs some required services on the behalf of the principal, whereas the principal commits to compensating the agent accordingly [61-63]. As a result, the principal seeks the most efficient contract, while agency models predominantly consider the principal's perspective [61]. Consequently, agency theory is primarily focusing on "the most efficient contract governing the principal-agent relationship", because opportunistic behaviors (agency problems) are expected to occur based on four underlying assumptions [60,62]:

1. Given that both principals and agents are motivated by economic self-interest to maximize profits (homo oeconomicus), goal conflicts between the two parties emerge that cause agency problems [60-64].

2. Therefore, agents are motivated to withhold information that is of interest to the principal, or the agent is driven to convey false information about its efforts during the contract, i.e., information asymmetries are likely to occur [61]. In this context, the degree of information asymmetry determines the possibilities of opportunistic behavior in the agency relationship [65]. Bergen et al. (1992) differentiate between two models of agency problems that emerge: hidden information (adverse selection), which arises ex-ante, i.e., pre-contractually, and hidden action (moral hazard), which arises ex-post, i.e., post-contractually. Meanwhile, other authors divide hidden information imbalances into hidden characteristics, hidden intentions, and hidden information/knowledge, allowing for a more detailed analysis of agency problems [64-67].

3. Principals and agents have different attitudes toward risk, which may lead both parties to take different courses of action, thus creating conflicting goals $[60,61,68]$. Traditionally, agency theory argues that the principal is risk neutral, while the agent is risk averse [61,62,69].

4. However, it is expected that environmental uncertainties outside of each actor's control may affect the outcome $[64,66,69,70]$. Hence, as one party needs to bear the risk, it is assumed that principals shift risk to the agents when outcome uncertainty is high $[60,61,71]$.

In response to the agency problems, formulating an appropriate compensation contract is vital to reduce goal conflicts and information asymmetries by considering behaviorbased versus outcome-based contracts $[43,61,71]$. Nevertheless, both contract types are per se incomplete $[64,72,73]$ and tied to agency costs [61], such as time and costs for measuring behavior or outcome [60,69]. Accordingly, safeguards [26] have been introduced as complementary means, comprising incentives and sanctions as supportive mechanisms to align the agent's interests with the principal's own goals [25,67,73,74]. However, it needs to be noted that these additional safeguarding activities incur further (agency) costs [69].

\subsection{Applicability of Agency Theory on the Implementation of Social Standards in Multi-Tier Apparel Supply Chains}

In the context of supply chain management (SCM), previous researchers successfully employed agency theory to investigate the interaction of buyer-supplier relationships [36,70]. Fayezi et al. [36] state, the "theory identifies behavioral change by supply chain actors and sheds light on activities involving principal and agent, self-interest, risk aversion, lack of trust, goal conflict, and imperfect policy implementation". Although researchers point at the explanatory power of agency theory in SCM disciplines [75], only few researchers adopted agency theory to investigate the use of social standards in multi-tier 
supply chains [25,34,55,76,77]. In their study, Delbufalo and Bastl [77] argue that social standards such as BSCI, SA8000, or WRAP contain elements of both behavior-based and outcome-based contracts to justify the applicability of agency theory.

It is noteworthy that agency theory traditionally focuses on dyadic relationships but needs to be extended when approaching a multi-tier supply chain setting, as one supply chain actor can occupy both the principal and agent role [34,36,78]. Hence, when applying agency theory to an "indirectly" managed multi-tier supply chain [33], the buyer is considered as the principal, and the sourcing agent is an agent to the buyer. Following this logic, the sourcing agent is principal to the first-tier supplier and the first-tier supplier an agent to the sourcing agent. Accordingly, the first-tier supplier is a principal to the lower-tier supplier and the lower-tier supplier an agent to the first-tier. As all upstream supply chain actors assume the role of an agent for the implementation of social standards, opportunistic behavior can be expected, which translates into social standard implementation failures [25]. Pedersen and Andersen [26] emphasize that social standard implementation is prone to opportunism due to (agency) costs and time incurred, usually driving suppliers to violate standards for financial gains. Hence, the rationale behind opportunistic behavior that leads to social standard implementation failures may arise due to agency variables governing multi-tier supply chain settings [33]. Borrowing from agency theory, these variables include goal conflicts, information asymmetries, risk attitude, outcome uncertainty, and safeguards, which may affect successful social standard implementation in multi-tier fashion supply chains [25,36]. Drawing on the literature on multi-tier SSCM and social standard implementation, Figure 1 has been developed and proposes the exploratory research framework of this study. The main components of the guiding framework will be discussed in the following sections and justify the applicability of agency theory to social standard implementation in multi-tier apparel supply chains.

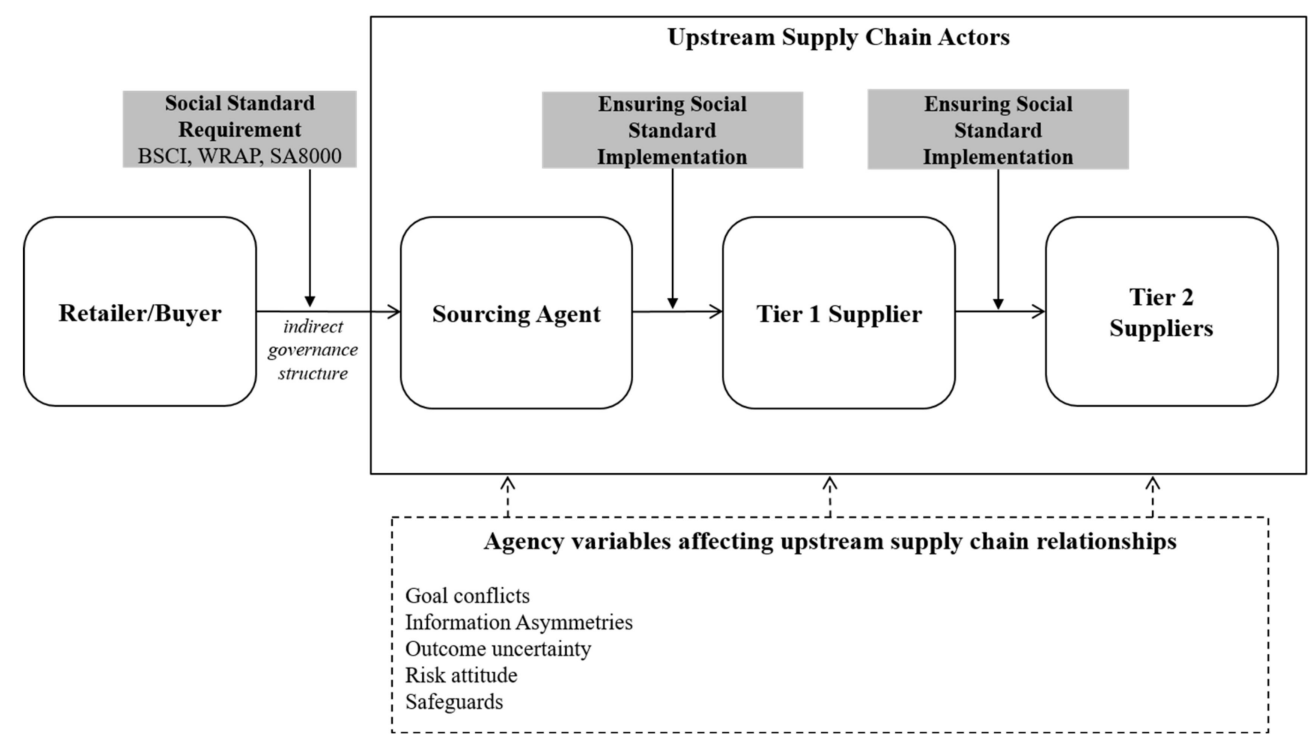

Figure 1. Exploratory research framework.

\subsubsection{Goal Conflicts and Information Asymmetries in Multi-Tier Fashion Supply Chains}

Besides downward price and lead time pressures, suppliers are additionally required to implement the fashion retailer's required social standard(s) [12,31]. This implies that on the one hand, suppliers need to offer highly competitive price and lead time conditions in order to win the contract, while on the other hand, agency costs emerge due to the assumed double agency role that, e.g., first-tier suppliers assume. These agency costs usually comprise additional time and costs for successful social standard implementation, ensuring compliance with lower-tier suppliers [34]. For example, the costs for consulting a third-party to audit the supplier accordingly $[7,15,16]$ or respective corrective actions require further costs typically carried by the suppliers $[11,26,79]$. These costs might drive 
substantial goal conflicts among supply chain members [31,80]. Additionally, fashion supply chains are typically plagued by transparency issues because of their highly complex and globally fragmented character with multiple (lower-tier) suppliers located in different countries [12,31]. Therefore, information asymmetries are likely to occur, and it is difficult for the buyers to monitor the supplier's behavior. Although previous research argues that social standards can be a tool to reduce information asymmetries $[17,76,81]$, it can be assumed that developing country upstream suppliers may have an economic incentive to convey false information about their efforts for social standard implementation and behave opportunistically for financial reasons $[23,25,26]$.

\subsubsection{Risk Attitude for Social Standard Implementation}

Against the traditional view of risk neutral principals and risk averse agents, it has been argued that this might be different in a multi-tier supply chain context, especially due to reputational and economic consequences in case of social issues in the supply chain $[4,82,83]$. Hence, in buyer-supplier relationships, apparel retailers (principal) are assumed to be highly risk averse, due to the potential consequences in the case that stakeholders detect social issues in their supply chains and attribute these violations to the retailer's social accountability $[1,4,25]$. However, sourcing agents and suppliers are expected to be highly risk averse as well, because they can be held accountable by the respective buying firms for causing social standard implementation failures leading to reputation and order losses [17,84]. In light of the risk attitude of each supply chain actor, at least one of the actors needs to bear the risk for ensuring successful social standard implementation. Therefore, the responsibility and willingness to accept the risk for ensuring successful implementation might fuel goal conflicts in multi-tier supply chain relationships.

\subsubsection{Social Standard Implementation Uncertainty}

As learned earlier, risk attitude in principal-agent relationships is further affected by environmental uncertainties outside of each actor's control. In this context, social standard implementation success is affected by external and internal supply risk sources typical for global supply chains [85-88]. For example, in the apparel industry, external supply risk sources comprise specific country effects such as cultural differences, market competition, and low local law regulations [89], and internal factors can include supply capacity problems or low managerial skills $[12,84]$, which can deteriorate the success of social standard implementation. Given the external and internal supply risks that potentially hinder social standard effectiveness, agency theory suggests that buyers and suppliers are expected to take different courses of action, which may result in opportunistic behavior $[4,36,71]$.

\subsubsection{Safeguards}

In order to minimize the potential for social standard non-compliance, the buyer can initiate safeguards that usually comprise incentives and sanctions $[25,26,90]$. For instance, Emmelhainz and Adams (1999) indicate that commonly used penalties imposed by apparel retailers in case of non-compliance are corrective actions, termination of relationship, and cancellation of orders. Other authors discuss that cost sharing practices or financial support provided by apparel retailers will lead to higher rates of social standard implementation success [17]. Further authors specify that incentives such as reputation effects, price premiums, offering long-term orders, and collaborative partnerships will motivate suppliers to adopt and comply with social standards, thus reducing opportunistic behavior $[39,80,89]$.

\section{Methodology}

\subsection{Research Design}

Given the early stages of social sustainability research and the ongoing lack of empirical evidence from developing countries, which serves the SSCM and social accountability debate, the author adopts a qualitative multiple-case study approach [91-93]. Moreover, 
this study follows implications of other researchers in the field and draws on assumptions of agency theory with the objective to explore failures in social standard implementation in apparel supply chains in order to extend and develop existing theory [77]. The chosen research design is useful to provide rich and detailed understanding of a contemporary phenomenon within its real-life context, allows for triangulation of data, and enhances validity concerns of the research [92-94]. Moreover, academics explicitly underline the strength of multiple case study designs, particularly in producing convincing and robust evidence by means of replication logic, increasing generalizability and offering an in-depth exploration of the outlined research questions [92,93,95].

By considering the latest literature reviews, using case study methods in SSCM disciplines has been proved to be useful $[5,36,96,97]$. In fact, case study research in SCM provides opportunities to build on theory, but also to develop theory [94,98-100]. Hence, as the paper at hand aims to develop theory, case studies are suitable [91,92]. In line with the theoretical research framework, the researcher is able to guide data collection and analysis deductively; however, this study allows for inductive findings to extend and develop theory accordingly $[92,94,95,97]$. By doing so, it outlines propositions that aim to explain social standard implementation failures in apparel supply chains. It is important to note here that it is not the major aim to test agency theory, but rather to use its tenets to interpret the findings following a theory, suggesting an explanation approach proposed by Zorzini et al. (2015). The units of analysis are the social standards, i.e., BSCI, WRAP, and SA8000. To ensure rigor and quality of the research process and design chosen, the researcher primarily follows the guidelines of Ridder [92], Eisenhardt and Graebner [91], Seuring [99,100], Yin [93], and Voss et al. [94].

\subsection{Case Selection}

The case study locations were primarily Vietnam and Indonesia. Both are among the Top 10 largest clothing exporters in $2017[13,101]$ with their largest markets being the U.S., Japan, and Europe [102,103]. Over the past years, Vietnam and Indonesia embraced sustainability initiatives, and apparel factories in both countries are primarily accredited by SA8000, BSCI, WRAP, Sedex, Better Work, and FLA to tackle social responsibility concerns $[13,101]$. This makes both countries ideal research objects for the outlined research questions. Cases in each of the countries were carefully chosen according to replication logic [93] with the intention to reflect an indirectly governed multi-tier supply chain setting that is in accordance with the proposed research framework in Figure 1. The supply chain position of each case can be extracted from Table 1. It is important to note that all the participant Tier 1 suppliers (Fact $1 \mathrm{~V}-4 \mathrm{~V}$ and $1 \mathrm{I}-5 \mathrm{I}$ ) in the study are primarily active in the FOB (Free on Board) export market. One distinctive feature appeared in Indonesia, as the researcher was able to include a Tier 2 supplier, i.e., local non-export CM (contract manufacturer) (Fact 6I), which is primarily active for the local market and thus holds no export license and no international social standard certification, although frequently processing orders for well-known western apparel brands, of which one is a client of Int I. As both sourcing agents are suppliers for one prominent European apparel retailer (Ret), the researcher included this particular buyer as a research case resulting in 13 cases (Table 1). 
Table 1. Case company profiles.

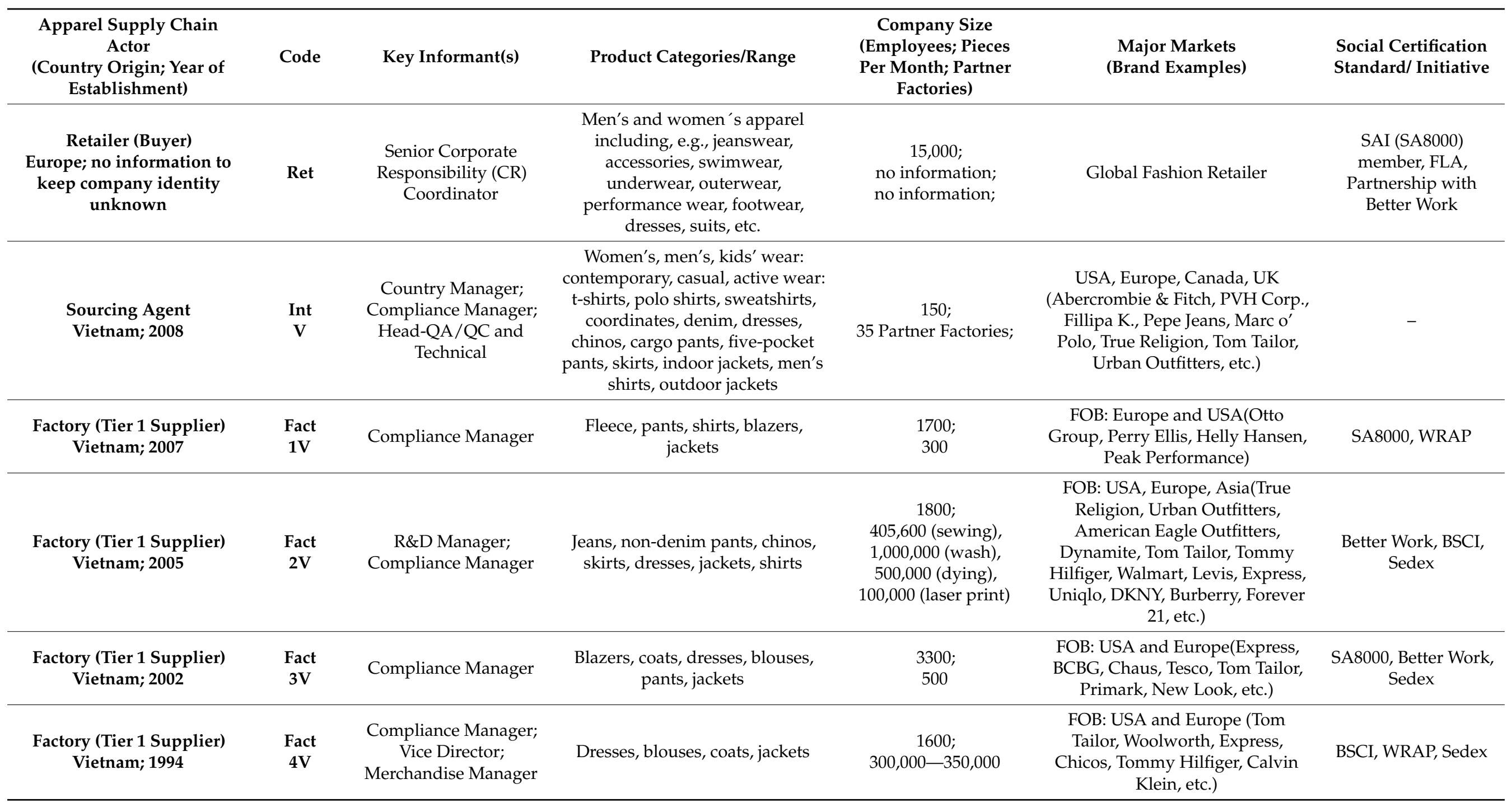


Table 1. Cont.

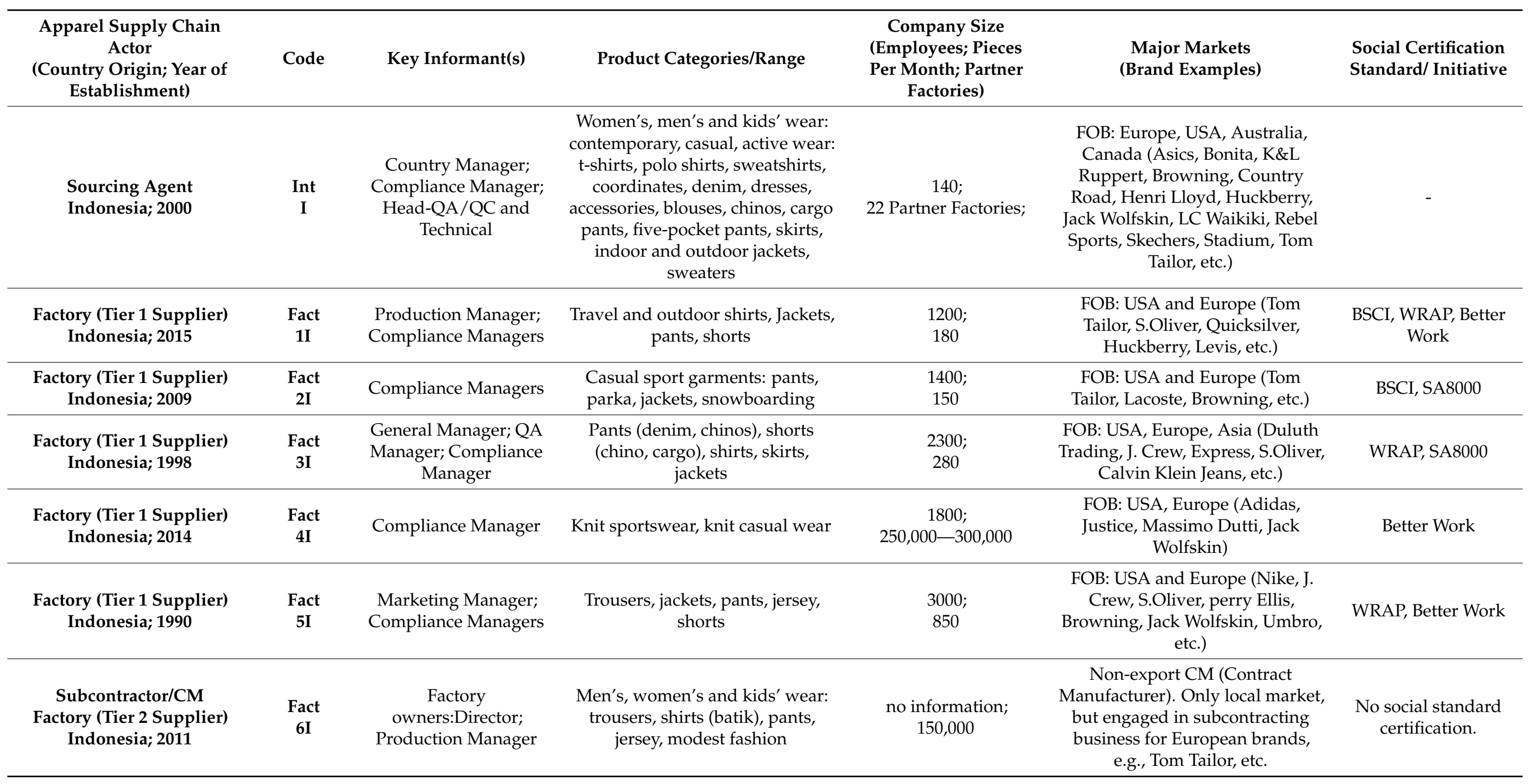




\subsection{Data Collection and Analysis}

Data were collected in Europe, Vietnam, and Indonesia between March 2017 to May 2018. Based on the research framework guiding the study, the researcher developed an interview guide (see Appendix A). To increase reliability of the multiple-case study, the researcher prepared and utilized a case study protocol $[92,93,104]$. A total of 13 face-to-face semi-structured interviews lasting 60-90 min were conducted.

In each case company, key informants accepted to participate and provided extensive and sensitive information. Depending on the informants' preference in Vietnam, the interviews were carried out in English or Vietnamese and translated when necessary. In Indonesia, all interviews were conducted in English. All interviews were audio recorded and transcribed. Further, the researcher was allowed to discuss findings subsequent to the interview, but also to contact the informants through follow-up mails and mobilephone messages to review transcripts, validate given information, and ensure clarity when needed. Data were further supplemented with multiple sources of sensitive secondary data relevant to the research objective, supporting triangulation and hence increasing validity $[93,94,100]$. This includes detailed company profiles, third-party social audit reports (i.e., BSCI, WRAP, SA8000), respective corrective action plans, social audit selfassessment checklists (including initial audit checklists by sourcing agents), case company policies and codes of conduct, but also intensive observational material on site such as pictures, videos, and notes.

For data analysis, a computer-assisted software MAXQDA (MAX-Qualitative Data Analysis) was employed. The semi-structured interviews and all additional material of the 13 cases were coded by using the thematic qualitative text analysis guideline proposed by Kuckartz [105]. This follows a two-step analysis including within-case and a subsequent cross-case analysis $[94,106]$. Table 2 summarizes the respective main thematic categories derived from the theoretical research framework (Figure 1). Accordingly, each interview and supplementary data were assigned case-by-case and line-by-line to the deductively derived main thematic categories as suggested in Table 2. The respective emerging subcategories have been included inductively. Subsequently, code-relation analysis was performed, offering insights to causal relationships of the categories, hence allowing for the development of propositions and the theoretical framework in Figure 1 [105]. Quality was enhanced by performing four suggested tests by Yin [93]. Construct validity was addressed by considering multiple sources of evidence, and where possible, the chain of evidence was established by collecting information from two or more interviewees of each case company. Key informants were asked to review transcribed and summarized data [100]. By using the agency theory lens for the interpretation of the findings, internal validity was addressed and allows for pattern matching $[93,97]$. External validity was attained by replication logic with cross-case analysis. Reliability was achieved by developing a case study protocol and case study database (Yin, 2009, 2014). Additionally, coding reliability was ensured, as the main thematic categories are theory-based and have been clearly defined in Table 2 . Inter-coder reliability was addressed by the involving one assistant researcher in the coding process, as the cases have been analyzed separately $[105,107]$. It is noteworthy that the researcher only presents findings of the cross-case analysis. 
Table 2. Main thematic categories guiding the study.

Theme

Description for Main Category Application

Principals and agents are motivated by economic self-interest to maximize their own profits (homo oeconomicus). Thus, different goals between buyers and upstream suppliers emerge, which cause agency problems and impede social standard implementation success.

Upstream suppliers have better information about their tasks, abilities, actions, or preferences, which cause agency problems. Accordingly,

Information asymmetries upstream suppliers are motivated to withhold social standard specific information that is of interest to the principal, or the upstream suppliers are driven to convey false information about their efforts for social standard implementation.

\section{Agency theory}

assumptions governing multi-tier apparel supply chains for social standard implementation ensuring compliance, e.g., monitoring activities, investments,
Main Category
Costs and time incurred for social standard implementation and

Agency costs corrective actions, etc.

The success of social standard implementation is affected by external and internal supply risk sources, e.g., cultural differences, market competition, low local law regulations, capacity problems, or low managerial skills.

Buyers and suppliers may have different attitudes towards risk due to reputational and economic consequences in the case of social standard implementation failures. Hence, the degree of risk aversion dictates the willingness to accept the risk and responsibility for ensuring successful social standard implementation.

Risk attitude

Supporting Literature

Bergen et al., 1992; Eisenhardt, 1989b; Göbel, 2002; Jensen \& Meckling, 1976; Perrow, 1986; Delbufalo, 2018; Delbufalo \& Bastl, 2018; Fayezi et al, 2012; Zu \& Kaynak, 2012; Bhaduri \& Ha-Brookshire, 2011; Hoejmose et al., 2014; Halldórsson et al., 2015; Short et al., 2016; Stigzelius \& Mark-Herbert, 2009; Wilhelm et al., 2016; Whipple \& Roh, 2010

Bergen et al., 1992; Schölermann, 2003; Wilhelm et al., 2016 Delbufalo, 2018; Delbufalo \& Bastl, 2018; Ciliberti et al., 2011

Gilbert et al., 2011; O’Rourke, 2003, 2006; Huq, Stevenson, \& Zorzini, 2014; Köksal et al., 2017; Emmelhainz \& Adams, 1999; Masson et al., 2007; Pedersen \& Andersen, 2006; Delbufalo \& Bastl, 2018

Outcome uncertainty

Choi \& Krause, 2006; Giannakis \& Papadopoulos, 2016; Keow Cheng \& Hon Kam, 2008; Whipple \& Roh, 2010;

Zsidisin \& Ellram, 2003; Perry \& Towers, 2013; Stigzelius \& Mark-Herbert, 2009; Yu, 2008
Busse, 2016; Fayezi et al., 2012; Hajmohammad \& Vachon, 2016; Rungtusanatham et al., 2007; Gualandris et al., 2015; Wilhelm et al., 2016 
Table 2. Cont.

\begin{tabular}{|c|c|c|c|}
\hline Theme & Main Category & Description for Main Category Application & Supporting Literature \\
\hline \multirow{4}{*}{$\begin{array}{l}\text { Agency problems } \\
\text { opportunistic behavior of } \\
\text { upstream supply chain } \\
\text { actors, which result in } \\
\text { social standard } \\
\text { implementation failures }\end{array}$} & Hidden characteristics & $\begin{array}{l}\text { Ex-ante, the buyer has incomplete information on the suppliers } \\
\text { capabilities and qualification for ensuring social standard compliance. } \\
\text { Therefore, pre-contractually, the supplier may misrepresent its } \\
\text { capabilities for social implementation and compliance in order to win } \\
\text { the contract. }\end{array}$ & \multirow{4}{*}{$\begin{array}{l}\text { Broens, 2016; Göbel, 2002; Saam, 2007; Schölermann, 2003; } \\
\text { Spremann, 1990; Steinle et al., 2014; Welge \& Eulerich, 2014; } \\
\text { Wiese \& Toporowski, 2013; Arnold Picot Christine } \\
\text { Bortenlanger, 1997; Hess, } 1999\end{array}$} \\
\hline & Hidden intentions & $\begin{array}{l}\text { Ex-ante, the buyer is not able to predict whether the supplier may } \\
\text { have the intention to act opportunistically during the contract period. } \\
\text { Consequently, hold-up problems may emerge, because the buyer } \\
\text { made specific irrevocable investments supporting the relationship to } \\
\text { foster social standard implementation. However, ex-post, distinctly } \\
\text { visible unfair practices that violate social standards during the } \\
\text { contract will corrupt these invests. }\end{array}$ & \\
\hline & Hidden actions & $\begin{array}{l}\text { Ex-post, opportunistic behavior performed by the supplier becomes } \\
\text { apparent in the lack of effort, the ability to shirk with guile or in other } \\
\text { words to cheat, mainly attributed to the self-interested behavior } \\
\text { assumption. These actions are invisible, and it is assumed that the } \\
\text { buyer's limitation to monitor and evaluate the suppliers efforts to } \\
\text { comply with social standards. }\end{array}$ & \\
\hline & $\begin{array}{l}\text { Hidden information/ } \\
\text { knowledge }\end{array}$ & $\begin{array}{l}\text { Ex-post, the supplier has private knowledge on environmental } \\
\text { influences and processes that are relevant to evaluate social standard } \\
\text { implementation success. This knowledge is part of the supplier's } \\
\text { professional or process knowledge, which he may use } \\
\text { opportunistically. }\end{array}$ & \\
\hline \multirow{2}{*}{$\begin{array}{l}\text { Safeguards } \\
\text { used to motivate and } \\
\text { improve social standard } \\
\text { implementation success in } \\
\text { multi-tier supply chains }\end{array}$} & Incentives & $\begin{array}{l}\text { For example, higher order volumes, long-term orders/relationship, } \\
\text { and price premiums offered by buyers for successful social standard } \\
\text { implementation by upstream suppliers. This also includes reputation } \\
\text { effects, which improve public recognition of upstream suppliers, } \\
\text { which can lead to increased business with orders from other buyers. }\end{array}$ & \multirow[t]{2}{*}{$\begin{array}{l}\text { Delbufalo, 2018; Pedersen \& Andersen, 2006; Porteous } \\
\text { et al., 2015; Delbufalo \& Bastl, 2018; Emmelhainz \& Adams, } \\
\text { 1999; Sartor et al., 2016, Huq et al., 2016, 2014; Yu, } 2008\end{array}$} \\
\hline & Sanctions & $\begin{array}{l}\text { For example, penalties such as corrective actions, reduced business, } \\
\text { fines, or termination of contract with the supplier in case of social } \\
\text { standard violations }\end{array}$ & \\
\hline
\end{tabular}




\section{Results}

Drawing on the deductive main categories suggested in Table 2, this section presents the cross-case findings of the 13 case study companies. Accordingly, Table A1 (see Appendix A) depicts the main categories and related subcategories, which emerged from the data (inductive).

By performing code-relation analysis, various causal links between the main categories in Table A1 (see Appendix A) have been detected, suggesting nexus of agency variables, which finally result in agency problems, i.e., social standard implementation failures in indirectly governed multi-tier apparel supply chains:

- Goal conflicts are primarily caused by the apparel retailer's unfair buying practices, the risk attitude of each supply chain actor, and the lack of safeguards for social standard implementation. The inductive findings suggest that it is misleading to exclude apparel retailers from the analysis, as an apparel retailer's unfair buying practices have direct effects on the degree of goal conflicts further upstream the supply chain. The higher the degree of conflicting goals, the more upstream supply chain actors are willing to exploit information asymmetries.

- The degree of information asymmetries is naturally high. Due to spatial and cultural distance, it is difficult to monitor each upstream supply chain actor's behavior to ensure effective social standard implementation and hence this provides space for social standard implementation failures.

- Risk attitude for social standard implementation is affected by social standard implementation uncertainty. The effective implementation of social standards depends on internal and external supply risks typical for multi-tier apparel supply chains. Except for the Tier 2 supplier, all other supply chain actors are found to be highly risk averse; however, sourcing agents and Tier 1 suppliers are pressured to accept the risk for ensuring social standard effectiveness.

Figure 2 illustrates the key findings based on the described links between the agency variables in multi-tier apparel supply chains.

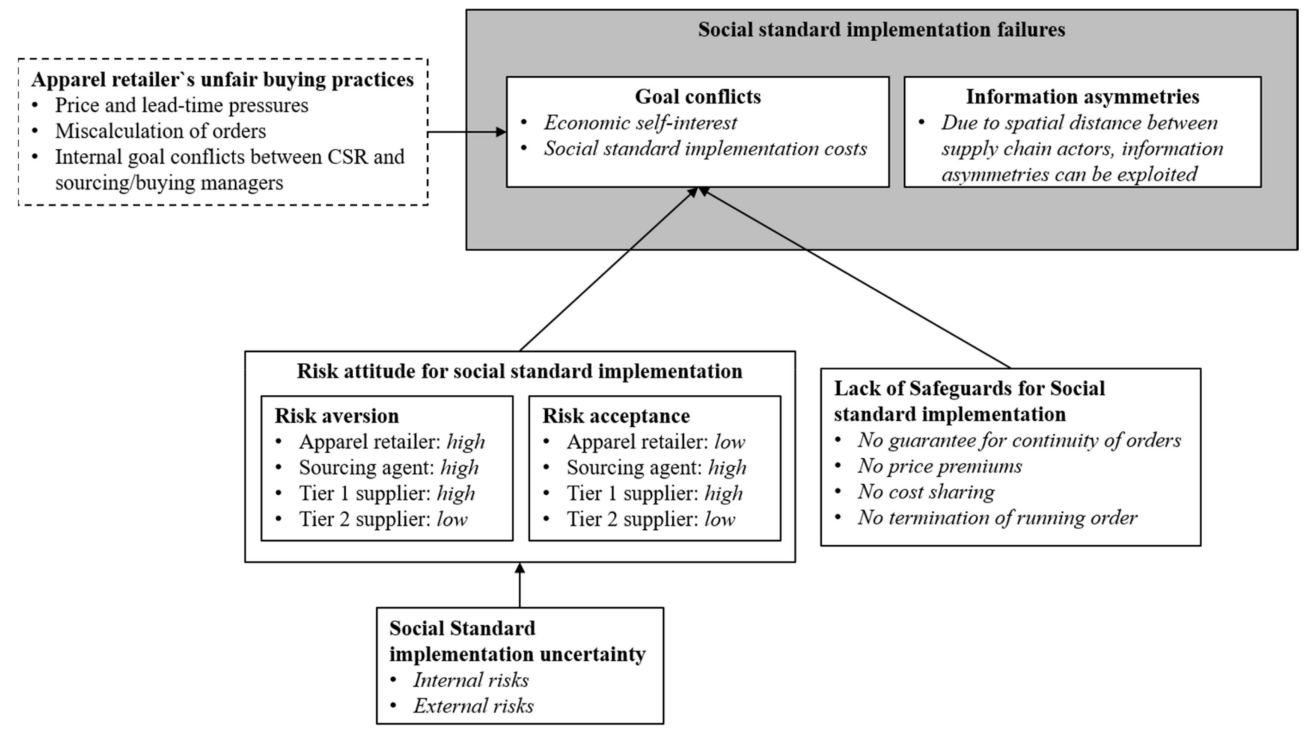

Figure 2. Relationships of main categories based on code-relation analysis.

As can be extracted from Figure 2, goal conflicts and information asymmetries in indirectly governed multi-tier apparel supply chains are the main antecedent variables for social standard implementation failures. In accordance with Table A1 (see Appendix A), the next sections present each agency variable depicted in Figure 2 through supportive multiple evidence provided by the cases. 


\subsection{Exploiting Information Asymmetries in Multi-Tier Apparel Supply Chains}

Given the prevalent information asymmetries explained by the cases (13), the following social standard failures have been primarily detected in Vietnamese and Indonesian apparel supply chains: excessive overtime (13), mock compliance (12), subcontractor social audits/monitoring (12), health and safety (11), compensation/wages and benefits (12), and trainings for production workers (10). Information asymmetries have been discussed as a natural "transparency" problem of apparel supply chains. Due to the spatial distance between the supply chain actors, information imbalances are often exploited by upstream suppliers. In this regard, all cases admit that multi-tier apparel supply chains typically suffer from the distance between supply chain actors, and this makes it difficult to monitor social standard effectiveness on a frequent basis. In fact, all Indonesian and Vietnamese upstream suppliers confirm that substantial goal conflicts will drive them to take advantage of the evident information asymmetries by performing opportunistic behavior. The resulting agency problems are likely to corrupt social standard implementation with the aim to compensate uneven benefits. Although social standards require third-party audits, the increasing information imbalance in between these social audits provides plenty of opportunities for opportunistic behaviors. The interviewees mention that excessive overtimes, mock compliance, and subcontracting activities are frequently conducted by Tier 1 suppliers with the ultimate aim to save costs, meet target lead times, or process unexpected orders.

"To be honest with you, the biggest problem in almost every factory is overtime [ ... ]

That is the biggest challenge, and not only in Vietnam, it might be everywhere in Asia"

(Int V-Head QA/QC and Technical).

Interestingly, the cases discuss excessive overtimes as a primary cause for health and safety issues, because factory workers will lose their concentration and motivation to keep up with health and safety guidelines. In this regard, mock compliance was discussed as an effective practice to cover up excessive overtimes and health and safety violations during social audits. The primary aim is to cheat on third-party auditors by using double records for working hours, but also by preparing their facilities and workers for potential interviews during third-party social audit days to convey compliance. The majority of cases frankly discussed that announced and semi-announced third-party social audits are worthwhile to engage in mock compliance. Another interesting violation emerged during analysis, as the cases frequently mentioned cheating on payroll documents. Here, Tier 1 suppliers are motivated to save tax by paying out overtime compensations or insurance payments in cash to the workers.

In the case of subcontracting activities to Tier $2 \mathrm{CMs}$, sourcing agents or Tier 1 suppliers are obliged to inform the retailers and ensure that the respective subcontractor follows the required social standard's principles:

“... you don't know, really, if sourcing agents or suppliers will go to subcontract to outside or not, because your brands will not stay everyday here. Only in our industry, we know that this kind of problem always happening."

(Fact 2V—R\&D Manager)

However, the latest third-party audit protocols of the Tier 1 suppliers unveil that Tier 2 CMs usually remain unchecked for their social performances, indicating that both sourcing agents and Tier 1 suppliers violate social standard requirements. The respondents confirm that in most cases, no proper subcontractor monitoring and audit systems are in place. For example:

"... you have to have people here to monitor the subcontractor. But we cannot do that for 24 hours to control the subcontractor, because sometimes these factories are also far away." 
Notably, the interviewees reveal that embroidery, printing, and washing processes are not considered to be main processes and thus are typically subcontracted to local Tier $2 \mathrm{CMs}$. Therefore, in the case that these sub-processes are passed to Tier $2 \mathrm{CMs}$, retailers and sourcing agents usually turn a blind eye and do not follow up Tier 1 suppliers to conduct social audits and monitoring activities at their subcontractors due to rising costs and time incurred.

\subsection{Goal Conflicts in Multi-Tier Apparel Supply Chains}

As shown in Table A1 (see Appendix A), the most critical antecedents for goal conflicts are economic self-interest and social standard implementation costs. In sum, it turns out that each of the supply chain actors agree to be highly self-interested to maximize their profits (13), while upstream suppliers bear the highest costs for the implementation of social standards (13). The findings show that social standard implementation is tied to high costs typically borne by upstream supply chain actors and thus deteriorates their economic (self-interest) performance. The cases dominantly discuss that the economic benefits of social standard implementation are higher for apparel retailers who can show up their social accountability to stakeholders, while upstream suppliers need to deal with the costs, besides offering low prices, short lead times, and high flexibility, to win orders.

\subsubsection{Economic Self-Interest}

The case study findings clearly show that the economic self-interest of the retailer becomes visible through pressures on price and lead times, while insisting on social standard implementation. All cases agree that these parameters ultimately determine order winners but create inevitable trade-offs, which upstream suppliers need to deal with. Ret's CR Manager confirms that economic parameters are prioritized in the company, and it is unpromising to put across sustainability goals that potentially risk the performance of the buying/sourcing manager, who is highly price, quality and lead time oriented. Almost all upstream suppliers complain that retailers usually miscalculate orders (over/under buying of garments) due to inaccurate market demand predictions and flawed forecasts. This has been described as having far-reaching effects. For example, an under buy of garments typically results in unexpected orders, increasing the pressures on upstream supply chain actors to opt for excessive overtimes or subcontracting activities. Moreover, in light of inaccurate forecasts, suppliers need to deal with order uncertainties, limiting the ability to make long-term investments and plan future factory costs, e.g., building up a solid worker base.This uncertainty pressures suppliers for flexible and low cost labor.

"[ ... ] we (CR) are asking for the exact opposite. So the sourcing managers want fast production, they want things to get done on time, they want quality. They want all the things that will contribute to what we call overtime."

(Ret-Senior CR Coordinator)

"It can go very nicely in the factory, and suddenly there will be a month where there could be a lot of orders, where the overtime of $30 \mathrm{~h}$ goes to 50-60 h, because you have no choice because of unexpected orders."

(Int V-Head QA/QC and Technical)

In sum, the retailer's unfair buying practices have been described as the primary antecedent for goal conflicts further upstream in the apparel supply chain. This was further confirmed by Int $\mathrm{V}$ and Int $\mathrm{I}$, who state that the most competitive price offer is key to winning the order. Therefore, to fulfil their own economic goals, sourcing agents accept the low prices and short lead times offered by apparel retailers however pass on these pressures further upstream.

"Of course the buyer-supplier relationship is always based on price. During these times the economics overrules everything else. You know, everything is driven by profitability"

(Int I-Country Manager) 
"... there is a high pressure on the price and costs (from apparel retailers). So what is happening, we are focusing more on costs rather than the processes."

(Int I-Head QA/QC \& Technical)

Accordingly, all Tier 1 suppliers perceive sourcing agents as significantly profit oriented, constantly seeking higher profit margins by squeezing prices further through, e.g., auction-like processes. This fuels another significant goal conflict in the sourcing agentthe Tier 1 supplier relationship. Despite the high dependency on receiving orders from sourcing agents, the majority of Tier 1 suppliers surprisingly confirm that they reluctantly contract with agents (10), reflecting a relationship that is inherently conflictual before orders are even placed.

\subsubsection{Social Standard Implementation Costs}

All cases (13) agree that social standard implementation implicates high costs. However, apparel retailers have been described as the most isolated supply chain actor from social standard implementation costs (9). It turns out that retailers simply pass costs for standard implementation and compliance upstream the supply chain, i.e., to sourcing agents and Tier 1 suppliers (12). This forces upstream supply chain actors to spend time, human, and economic resources in order to keep up with the social standards' requirements and ensure its effectiveness.

"[ ... ] so far the costs are being pushed to the factory. Retailers only recommend for this third party and the auditor will come."

(Fact 5I-Compliance Manager)

"They [retailers] are like, I just like this, I want this, and you just think about that. But how I do, they don't care"

(Fact 2V—Compliance Manager)

Given that upstream suppliers are economically self-interested and plagued with price and lead-time pressures, the costs for social standard implementation and ensuring compliance cause considerable goal conflicts. The sourcing agents (Int I and Int V) primarily face costs for building a Tier 1 supplier base, which is capable of fulfilling orders in accordance with predefined prices, lead times, quality, and respective social standard requirements. Therefore, besides the technical audits, sourcing agents face high costs for conducting initial social audits in order to prepare prospective Tier 1 suppliers for thirdparty audits and thus support them in achieving social standard certification. Additionally, sourcing agents bear monitoring costs for ensuring that their supplier base keeps up with the social standard requirements.

"If you have 12 brands, you maybe have 12 different auditors here. So this is very costly [...] So in one week, maybe sometimes 2-3 auditors come and spend the time, taking a lot of time. We need to prepare so many documents and carry the costs. Yes, it's stress."

(Fact 3I-Compliance Manager)

As Fact 3I states, the most significant costs for Tier 1 suppliers are associated with the need for implementing multiple social standard requirements from multiple retailers. The related multiple certification and compliance expenses comprise increased equipment, labor, corrective action, and third-party accreditation costs. Additionally, in case of subcontracting, monitoring activities need to be in place and documented in alignment with the social standard requirements, which increases costs. This further demands substantial travelling and time expenses, as well as auditing/monitoring efforts on site. In fact, according to the latest social audit reports and documents of all Tier 1 supplier cases, subcontracting documents are either not in place, or incomplete and not prepared properly. Interestingly the Tier 1 supplier cases argue that they categorically will avoid air-freight penalties or discount claims (that can range between 5-10\%) imposed by the buyers and thus preferably opt for overtime and subcontracting in case of potential delivery problems, as this is more 
cost efficient to process the order timely. This even causes call-backs of workers for a second work shift during the night, as some respondents report, and induces considerable social standard failures.

\subsection{Social Standard Implementation Uncertainty}

As the cases reveal, social standard implementation in Vietnamese and Indonesian apparel supply chains is exposed to high outcome uncertainty due to typical supply risks sources that will deteriorate implementation effectiveness.

\subsubsection{Internal Risks}

According to the cases, the predominant internal supply risks include the cultural misalignment of western-based social standard requirements (13), low managerial capabilities at suppliers incurring flawed production planning (7), and production inefficiencies (5).

Respondents repeatedly note that factory workers are not willing to accept westernbased codes due to their culturally underpinned mindset and comfort reasons at work, especially concerning health and safety issues such as wearing safety shoes, gloves and masks, or blocking exit doors. Interestingly, the upstream supplier cases reveal that factory workers are proactively seeking overtime in order to achieve higher salaries, causing pressure to leave the factory for another that grants high overtime rates.

"They [competitor factories] will offer overtime and then we will lose workers [...] so no overtime, no workers, that's the problem."

(Fact 5I—Compliance Manager)

\subsubsection{External Risks}

External supply risks such as raw material delays (13), low governmental enforcement (6), and local and international market competition (9) have been mentioned most often by the cases.

The most critical factor discussed is the late arrival of raw materials at suppliers. This delay can have many causes, such as late payments by Tier 1 suppliers or raw material delays described as further factors, which threatens social standard implementation. In such cases, overtime is inevitable to keep up with order lead times.

"There are cases where China got the smog and fog. So the Chinese fabrics are coming late. So there is nobody who can resolve the issue. Customers just don't want to know"

(Fact 2V-Compliance Manager)

Moreover, the governments of both countries provide no support or incentives for socially responsible factories, have soft control mechanisms, i.e., less frequent monitoring activities to enforce social responsibility, keep their eyes closed during audits in favor of the factories because they are perceived as job creators and contribute to the local wealth, and are prone to bribery acts:

"In some cases, the factory can provide money for the authority person (during audit), a bribery act to waive the following local requirement."

(Int V-Compliance Manager)

Further, the "Hobson's choice" approach by retailers creates high competitive pressures, which force upstream supply chain actors to accept unfair contract conditions based on price, lead times, quality, and social standard requirements. As nine cases argue, retailers will simply offer the same contract conditions to other local suppliers or suppliers in other sourcing countries who are accepting the order. Hence, all upstream suppliers confirm that they are in a disappointing situation due to national and international competition.

"... so there is a competition that has come to us. So the buyer can choose from factories $[\ldots]$, so if you are not able to do that, the customer will say somebody else is doing it"

(Fact 1I-Production Manager) 


\subsection{Risk Attitude for Social Standard Implementation}

In fact, the most critical forces mentioned by eight cases were consumers, media, and NGOs that specifically pressure apparel retailers to adopt social standards to their supply chains and hence urge the need for social accountability.

"[ ... ] the most power seen in terms of consumers was the Greenpeace campaign where the chemical management became a huge issue (... ) I think NGOs, in terms of the platforms that are available to everyone, are very powerful, and they do reach out to more than one brand at the time"

(Ret-Senior CR Coordinator)

Although apparel retailers have been described to be highly risk averse due to high levels of perceived stakeholder pressures and reputation loss, they, surprisingly, transfer the risk for social standard implementation fully to the upstream suppliers. This was confirmed by almost all cases.

"Brands only want the certificate, nothing more!"

$$
\text { (Int I-Compliance Manager) }
$$

Sourcing agents (5) and suppliers (13) have been found to be highly risk averse, but perceive high pressures to accept the risk for ensuring effective social standard implementation. The primary pressures mentioned are the fear of customers leaving and the loss of access to the export market when failing to implement required social standards successfully. As apparel retailers create highly competitive conditions based on unfair contract conditions, they are able to transfer social standard responsibility to sourcing agents and suppliers. Consequently, sourcing agents (12) and Tier 1 suppliers (13) are forced to accept the social standard responsibility risk in order to win contracts, despite high uncertainties, to ensure effective social standard implementation.

"The pressure is to do the (social) audit well to get the order and to give good a price to get the order."

(Fact 4V—Compliance Manager)

"... if the merchandiser (of the factory) needs to take a risk, okay, we just confirm the order because we like the price, but we will take a risk for the production."

(Fact 2V-Head of R\&D)

Although apparel retailers, sourcing agents, and Tier 1 suppliers discuss high reputational and economic risks, the Tier $2 \mathrm{CMs}$ (Fact 6I) perceive low risks and consequences when they are involved in social standard implementation failures. As six cases explain, the Tier $2 \mathrm{CMs}$ merely focus on the local market and hold no export license; they are isolated from social standard implementation and compliance responsibility. Fact 6I's statements underline that they are not willing to accept the risk for social standard implementation, especially due to its costs and pressures for price and lead times typical for the export market.

"( ... ) it's the cost (for social standard compliance) and the orders right now. It's the pressure (... ) in the export market you miss to include those social standard costs in the price, right."

(Fact 6I-Director)

\subsection{Safeguards for Social Standard Implementation}

Despite the conflictual apparel supply chain setting, which threatens social standard implementation success, safeguards can be applied by the supply chain actors in a principal position to achieve goal congruence with their agents (upstream suppliers).

\subsubsection{Incentives and Sanctions in Use}

First, all cases agree that successful social standard implementation and compliance were related to enhanced reputation. Although the cases dominantly discussed that it 
protects the retailer from stakeholder pressures, all upstream supply chain actors mentioned beneficial reputation effects, which predominantly attract new buyers (13), but also facilitate big order placements (12). In the case of social standard violations and ineffective implementation, the most threatening sanction mentioned by the upstream supply chain actors is the termination of (pre-planned) future orders by retailers (12).

\subsubsection{Lack of Incentives and Sanctions}

It turns out that retailers typically backtrack from using incentives such as price premiums for successful social standard implementation, or any cost sharing activities or significant financial support, as these safeguards are related to additional (agency) costs (12). Consequently, based on economic self-interest (homo oeconomicus), the equal behavior overspills to the sourcing agent and the Tier 1 supplier's relationship and ultimately spreads out to the Tier 1-Tier 2 supplier relationship.

In this regard, interviewees point out that the continuity of orders is critical to achieve social standard implementation success. Despite this necessity, all sourcing agents and supplier cases (12) confirm that order continuity is not guaranteed when successfully implementing the requested social standards, although price, lead times, and quality from that particular buyer have been achieved in earlier orders. Additionally, interviewees criticize that in light of the downward price pressures, price premiums (12) and cost sharing practices (12) for social compliance are not existent in the typical apparel business.

"So far in all this trading business, there are no incentives for social compliance, and social parameters are pressurized [ ... ] there is also no buyer so far who is incentivizing because you are rated better in social compliance."

\section{(Fact 1I-Production Manager)}

Almost all interviewees (11) emphasize that due to time or market reasons, retailers backtrack from terminating a running order despite the fact that (major and minor) noncompliance findings have been revealed during social audits.

\section{Discussion}

Given that agency variables govern the apparel multi-tier supply chain (Figure 2), the next sections discuss the emerging opportunistic behaviors performed by the upstream supply chain actors. Readers should note that the author decided to omit hidden information/knowledge, because no evidence was provided that any principal is not capable of evaluating the agent's opportunistic actions due to lack of expertise or knowledge towards social standard implementation.

The findings of the study confirm that the use of social standards are the preferred tool when apparel retailers opt for an indirect governance approach to manage their supply chain for socially related issues. In alignment with prior studies, the findings demonstrate that the apparel retailer's unfair buying practices create highly competitive conditions in the sourcing market. This power imbalance, as discussed by SSCM researchers [4,27,33], becomes especially visible through the retailer's "Hobson's choice" approach, enabling them to shift the responsibility for successful social standard implementation to upstream suppliers and accept unfair conditions for the purpose of winning the order [2]. Yet, the literature discusses social standards as a promising tool to reduce information asymmetries and tackle transparency problems [76,81,84,97]. However, the findings of this study reveal that social standards are part of the problem in apparel multi-tier supply chains and motivate upstream suppliers to exploit prevalent information asymmetries rather than reducing them. In this regard, recall that opportunistic behavior detected in the cases translates into considerable failures to social standard implementation [25].

As can be extracted from Table A1 (see Appendix A), sourcing agents and Tier 1 suppliers are involved in hidden characteristics (11), hidden intentions (12), and hidden actions (12), causing significant social standard failures. Surprisingly, the Tier 2 CM is not considered as a performer of opportunistic behaviors (6). Drawing on code-relation 
analysis and by considering respective literature, the following sections discuss the upstream supplier's opportunistic behavior and how these behaviors lead to social standard implementation failures, allowing for the formulation of novel propositions. Ultimately, the proposed research framework guiding this study was complemented and developed as shown in Figure 3, which illustrates social standard failures in indirectly governed multi-tier apparel supply chains.

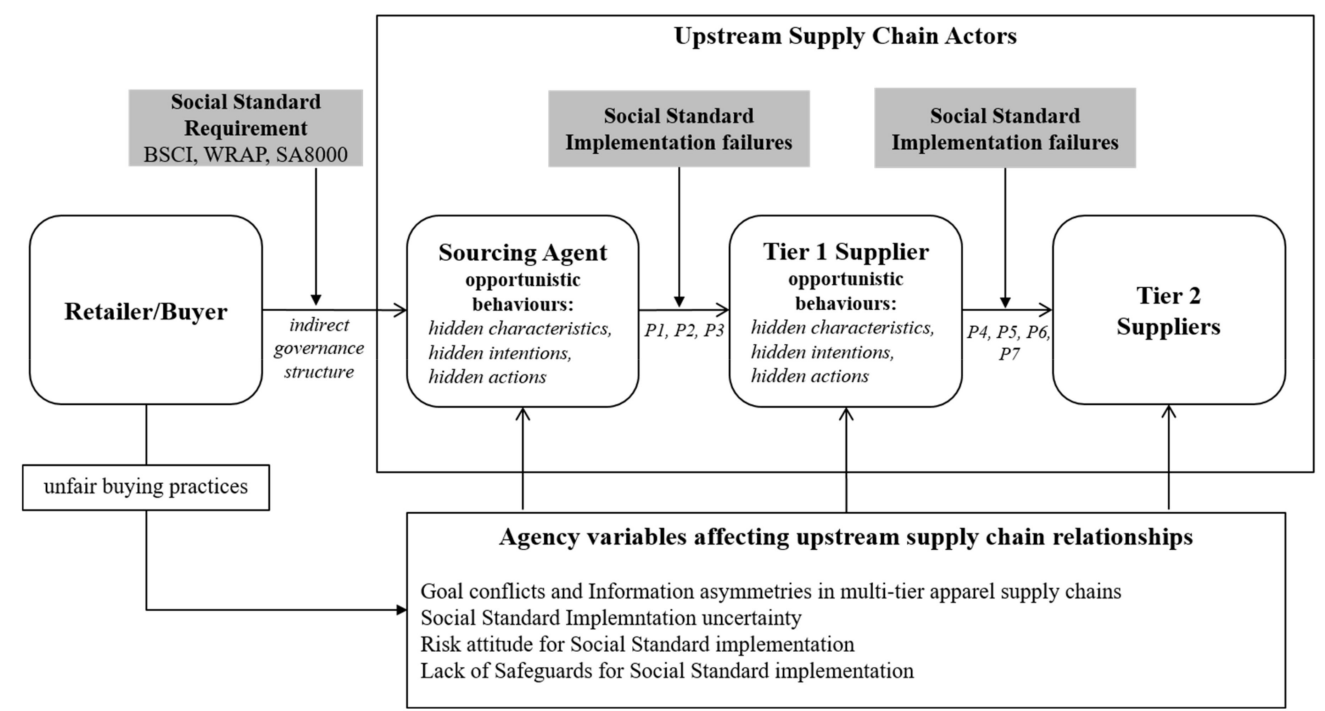

Figure 3. Revised framework illustrating social standard failures in indirectly governed multi-tier apparel supply chains.

\subsection{Sourcing Agent}

The sourcing agent, as an intermediary in the apparel supply chain [59], is an agent to the retailer (principal) and a principal to the supplier (agent). Hence, when apparel retailers opt for a mediated sourcing strategy, the risk for social standard implementation is typically shifted to the sourcing agent [57]. This provides room for considerable agency problems and opportunistic behaviors performed by the sourcing agent, explained in the following $[25,77]$.

\subsubsection{Hidden Characteristics}

Prior literature and the findings of this study confirm that downward price and lead time pressures exerted by apparel retailers cause unavoidable social standard implementation failures in the supply chain [12,31]. As found in this study, this is mainly attributable to the unfair sourcing practices of retailers [12], who are able to create highly competitive conditions. Given these pressures, sourcing agents are likely to accept low prices and short lead times offered by apparel retailers while promising to keep up with social standard requirements, although being aware that their Tier 1 supplier base might be capable of processing the order without violating social standards. Despite both sourcing agents in this study claiming that they want to avoid subcontracting, they reveal that it is often unavoidable in order to be on time for the agreed delivery date, knowing that this will cause social standard failures.

"You don't have any other option. These subcontracting activities are unavoidable circumstances in the garment industry."

$$
\text { (Int I-Head QA/QC and Technical) }
$$

Hence, although being risk averse, sourcing agents misrepresent their supplier base pre-contractually (ex-ante) in order to win the contract and pursue their economic selfinterest [11]: 
P1: The lower the prices and the shorter the lead times in indirectly governed multi-tier apparel supply chains, the more likely risk averse sourcing agents misrepresent (ex-ante) their Tier 1 supplier base capabilities to fulfil the order without compromising on effective social standard implementation.

\subsubsection{Hidden Intentions}

All of the social standards subject to this study require that subcontractors in use should be monitored by Tier 1 suppliers and at least be in accordance with the core principles of the respective social standard [44,46,47]. Nevertheless, the cases explicitly mentioned that sourcing agents cannot be monitored by western retailers on an permanent basis due to the spatial distance and respective monitoring costs, leaving effective social standard implementation at risk. This finding confirms prior findings that spatial distance increases information asymmetries [38,51,57].

Consequently, two scenarios can occur that threaten social standards when sourcing agents initiate subcontracting activities. First, hidden intentions can be assumed, because sourcing agents deliberately accept a contract with the retailer although they are not able to meet the agreed conditions that prohibit the unauthorized use of subcontractors. Sourcing agents, however, appear to be willing to subcontract the order (or parts of the order) when they need to cut costs or meet the lead time targets during the contract. In this case, when Tier 2 CMs are employed by sourcing agents post-contractually, they act unfairly but visibly to the principal [67], provided that the subcontracting activity is communicated to the retailer accordingly. This, however, leads to hold-up problems (sunk costs), because in this phase, the apparel retailer has invested in the relationship with the sourcing agent and is, post-contractually, heavily dependent on the sourcing agent to receive the order timely for the agreed price [11]. Despite the contractual agreements, the cases confirm that apparel retailers take subcontracting activities for granted just to meet lead time targets, contradicting to prior research findings [82].

P2: The shorter the lead times in indirectly governed multi-tier supply chains, the more likely sourcing agents have the intention (ex-ante) to act unfairly during the contract (ex-post) by subcontracting orders to Tier $2 \mathrm{CMs}$.

\subsubsection{Hidden Actions}

Although all Tier 1 suppliers agree that Int $\mathrm{V}$ and Int I can play important roles for social standard implementation and upgrade their facilities, there is evidence that the sourcing agents are likely to use information to their own benefit. This typically harms the other upstream suppliers, as they are the main mediators and coordinators between the Tier 1 suppliers and retailers [57,59]. For instance, in light of the external and internal social standard compliance uncertainty, first-tier suppliers are often not able to keep up with the required lead times. Hence, Tier 1 suppliers requests the sourcing agent to negotiate delivery date extensions with the retailer. As it is common for mediated sourcing strategies, the Tier 1 supplier usually does not have direct contact to the apparel retailer and hence are exposed to the information provided by the sourcing agent. This is typical in "open" or "indirect" governance of multi-tier supply chains $[33,54]$. In this regard, two problematic scenarios occur in this study. First, in the case that the apparel retailer grants an extension of the delivery date, the sourcing agent will keep a particular amount of buffer and reveal much shorter extra days to the Tier 1 supplier. The second scenario implies that the sourcing agent does not even ask for any extensions of the delivery and will purposely betray the Tier 1 supplier with the aim to meet the contractual lead times with the retailers and ensure a good performance in their eyes. In both scenarios, the retailer (principal) and the Tier 1 supplier (agent) are not able to monitor the apparel sourcing agent's behavior. As such, the apparel sourcing agent is likely to delude retailers and suppliers to create lead time buffers to keep its performance in the eyes of the retailers. This opportunistic behavior, however, leads to considerable non-compliance issues, i.e., overtimes at suppliers due to unnecessarily fueled lead time pressures at Tier 1 suppliers. 
P3: The shorter the lead times, the more likely sourcing agents are to withhold or modify lead time information to retailers and Tier 1 suppliers (ex-post).

\subsection{Tier 1 Suppliers}

As Tier 1 suppliers are the main subject of any social standard, they usually bear the highest costs for effective implementation [15-17,108]. In light of their economic selfinterest (homo oeconomicus) to stay competitively viable and maximize profits, Tier 1 suppliers perform considerable opportunistic behavior $[109,110]$. This is in line with previous findings, proposing that cost and benefit imbalances fuel goal conflicts because the buyer is closer to the end-customer and reaps higher benefits from social standards by enhancing its image and reputation [25,51,84,111,112]. In this regard, Baskaran et al. (2012) discussed that it is in fact lucrative for Indian garment suppliers to violate social concerns in order to improve their financial situation. The study's findings further support that the high dependency situation of Tier 1 suppliers on receiving orders from sourcing agents (or big retailers) minimizes their profits and causes high reluctance to establish a collaborative partnership towards social standard implementation. This is substantially fueled by the lack of appropriate safeguards, particularly cost sharing, price premiums, or a guarantee of continuous orders, which are usually not existent in multi-tier apparel supply chains [31,84]. Ultimately, this results in hidden characteristics, hidden intentions, and hidden actions, leading to social standard violations, as discussed in the following.

\subsubsection{Hidden Characteristics}

As evidence shows, merchandise and production planning managers of Tier 1 suppliers are generally order-winning oriented and heavily guided by price, lead times, and production capacity. This is in line with previous research, suggesting that Tier 1 suppliers constantly seek to close big order contracts with retailers and thus overstate their abilities, despite being highly risk averse [2,80]. More specifically, ex-ante, Tier 1 supplier managers are likely to signal the capability of processing the order in question for a specific price, within a specific lead time and quality required, despite lacking the production capacity and resources to process the order without compromising on social standard requirements [113]. Based on this, the social standard dilemma takes its course, as excessive overtime and subcontracting are the inevitable result.

"When we confirm the order, we don't calculate the overtime. So it's our thing about the planning part or efficiency part that comes to the picture."

(Fact 1I-Production Manager)

Given the hunt for closing big order contracts, Tier 1 suppliers' merchandise managers accept deficient prices, lead times, and unexpected orders based on too optimistic and flawed production planning.

P4: The lower the prices and the shorter the lead times in indirectly governed multitier apparel supply chains, the more likely risk averse Tier 1 suppliers are to misrepresent their production capability (ex-ante) to fulfil the order without compromising on effective social standard implementation.

\subsubsection{Hidden Intentions}

Drawing on the former proposition that highly risk averse Tier 1 suppliers close contracts at any "price", Tier 1 managers know ex-ante that they will not be able to process the order without violating social standards. This can be derived from the frank Tier 1 supplier statements to favor overtimes and subcontracting over air-freight penalty or discount claims, which would help to mitigate social standard violations. Accordingly, Tier 1 suppliers will perform visible unfair practices ex-post in form of violating overtime regulations or subcontracting to Tier 2 CMs. Based on this, a hold up emerges (sunk costs), especially because in the phase of a running production, the buyer (retailer or sourcing 
agent) is heavily dependent on the Tier 1 supplier to deliver the order on time, thus taking social standard violations for granted.

P5: The shorter the lead times in indirectly governed multi-tier apparel supply chains, the more likely risk averse Tier 1 suppliers are to accept orders (ex-ante) with the intention to act unfairly during the contract (ex-post), which causes social standard failures.

\subsubsection{Hidden Actions}

As learned earlier, when Tier 1 suppliers initiate the subcontracting activity, they become the actor responsible for conducting social audits and monitoring the local (nonexport) Tier $2 \mathrm{CMs}$ against the core principles of the social standard required by the buyer [34,114]. However, the Tier 1 supplier third-party audit reports and the interviewees reveal that Tier $2 \mathrm{CM}$ social audits and monitoring systems are likely to be neglected or even not performed due to additional costs that will arise [109]. Given the absence of proper incentives and sanctions (i.e., cost sharing, price premiums, guarantee for continuous orders, and termination of running orders), this cost saving activity emerges during the contract and thus translates into a moral hazard performed by Tier 1 suppliers.

P6: The higher social standard implementation costs and the lesser the use of proper safeguards in indirectly governed multi-tier apparel supply chains, the more likely Tier 1 suppliers are to violate social auditing and monitoring activities at Tier $2 \mathrm{CMs}$ (ex-post).

Furthermore, the majority of cases affirmed that mock compliance is still a very common practice in the garment industry $[23,80]$. This activity promises to pass the social audits without proper investments for, e.g., upgrading the facility for good audit ratings or corrective actions and ensuring good performances for overtime ratings. Therefore, hiding and cheating practices incur moral hazards to both retailers and sourcing agents (including the third-party auditors), because these actions remain invisible and hidden from the retailers or sourcing agents.

P7: The higher social standard implementation costs and the shorter the lead times in multi-tier apparel supply chains, the more likely Tier 1 suppliers are to perform mock compliance activities (ex-post).

\subsection{Tier $2 C M$}

Fact 6I primarily focuses on the local market and thus holds no export-license, especially to avoid price, lead time, and social standard implementation and compliance risks (i.e., low social standard responsibility acceptance).

\section{"[ ... ] local subcontractors (CMs) are not covered by the social certificates."}

(Fact 6I-Director)

This implicates that non-export Tier $2 \mathrm{CMs}$ oblige local law labor regulations but do not have direct obligations towards social standards [10,113]. Therefore, six cases discuss that no opportunistic behavior towards social standards is performed by Fact 6I, although there is general consensus that subcontracting business to Tier $2 \mathrm{CMs}$ is a critical risk to social standards and responsibility. This was further confirmed through on-site observations at Fact 6I, which is, among many others, obviously violating plenty of health and safety requirements. This includes missing indications for emergency exit ways; bulks of garments on production lines; entries, exits, and staircases; neglected sanitary and washrooms; fabric cutters not wearing gloves; workers not wearing masks or safety shoes; and no first-aid boxes or an in-house clinic at the site. In addition to that, as learned earlier, Tier 1 suppliers usually neglect their double agency role [34], i.e., social audits and monitoring at Tier $2 \mathrm{CMs}$ are ignored due to costs and time incurred, but also because there is little chance to enforce a social standard's principles at Tier 2 CMs. This is mainly because sourcing agents or Tier 1 suppliers are heavily dependent on their services to meet their prices and lead times [113], whereas Tier 2 CMs fulfil their economic interest primarily through the local market and process orders for the export market merely to gain additional profit. 


\section{Conclusions and Implications}

Despite the ongoing massive reports on social grievances in the apparel industry, the adoption of private social standards remains the most critical SSCM practice for retailers to manage (mitigate) social risks with suppliers and communicate social accountability to stakeholders $[7,8,35,49,82]$. Therefore, it is highly important to understand the dynamics that may impede the implementation success of social standards in multi-tier supply chains. Based on the evidence of 13 cases including developing country upstream suppliers, this study developed the conceptual framework in Figure 3 and proposed seven propositions explaining why upstream suppliers in indirectly governed multi-tier apparel supply chains perform opportunistic behaviors and how these behaviors cause social standard implementation failures. Ultimately, this study clearly demonstrates that social standard implementation in indirectly governed multi-tier apparel supply chains is a farce. Especially, apparel retailers need to rethink their perspectives on corporate social responsibility (CSR), particularly when requiring private social standard implementation and compliance from their upstream supply chain partners.

Therefore, this study primarily contributes in two ways: First, it demonstrates the applicability and explanatory power of agency theory for revealing social standard failures in a globally dispersed multi-tier apparel supply chain setting. Second, this study developed a conceptual framework (Figure 3) as a guide for industry players and SSCM researchers by illustrating how agency variables affect social standard implementation. Accordingly, seven testable propositions novel to the debate are presented. Based on this, various implications can be derived for apparel industry managers and social standard setters to critically scrutinize and reassess their current practices and behaviors.

\subsection{Implications for Effective Social Standard Implementation in Multi-Tier Apparel Supply Chains}

Given that information asymmetries are naturally existent in globally dispersed multitier apparel supply chains, it seems that the only promising way to ensure effective social standard implementation is to reduce goal conflicts. The developed conceptual framework offers several areas of actions to improve social standard implementation effectiveness in multi-tier apparel supply chains:

The internal goal conflict at retailers needs to receive close attention for effective social standard implementation. The study reveals that there is a high conflict of interest between the buying/sourcing and CSR departments, as price and lead-time performance prevail over social responsibility goals. Hence, CSR departments need to be empowered by awarding a more integrative role in product development, assortment planning, merchandising, and sourcing decisions. This also implies that CSR managers need to be capable of profound negotiation skills and have knowledge about the apparel industry's specific dynamics [115] to assert their interests internally to drive more socially oriented decisions $[97,116]$. However, as the literature suggests, the fundamental pre-requisites to achieve social sustainability goals are the fashion retailer's vision, organizational culture, and ethos, guided by ethical principles, values, and social responsibility. This ultimately will shape the top management's true commitment to social sustainable strategies and practice $[31,50,97,117]$.

Retailers still struggle considerably with adequate market demand predictions that likely result in unexpected orders for suppliers $[12,59,113]$. In this regard, the traditional fashion calendar, following a seasonal "push" approach of fashion products, needs urgent reconsideration [118]. For example, on-demand planning may facilitate smaller batch orders, and predefined order quantity limits can reduce over/under buy, which may decrease pressures at suppliers. In fact, the current fashion system came under scrutiny, as practitioners suggested a new "decentralized" fashion calendar with only two seasons and the elimination of off-season production [119]. Moreover, the advent of big data analytics provides promising opportunities to invest into data mining, warehousing and artificial intelligence systems to increase accuracy in fashion sales forecasting [120,121]. 
There is an urgent need to scrutinize how social standard implementation responsibility and risk are distributed among respective supply chain actors. Yet, this study reveals that fashion retailers assume low acceptance levels of social standard responsibility, although perceiving high social accountability risks [4]. As a consequence, social standard implementation responsibility and risk, and hence the respective costs are shifted to upstream supply chain actors, causing substantial goal conflicts in the entire supply chain. In this regard, policy makers and standard setters need to be aware that social standards suffer from significant power imbalances within multi-tier apparel supply chains.

The use of appropriate safeguards will support goal alignment when risk attitudes are considerably different among supply chain actors. Price premiums, cost sharing, and the guarantee for continuous orders is crucial in the formulation of contracts. These safeguards are critical to set up a commitment oriented and trustful relationship in global fashion supply chains [31,122], hence motivates upstream supply chain actors to ensure effective social standard implementation. For example, the need for order continuation is key for a supplier to plan future investments, labor force, and calculating factory costs. This will ultimately reduce the risk of overtimes, subcontracting, cheap labor or high fluctuation rates at suppliers.

Mediated sourcing practices can contribute to further goal conflicts and information asymmetries. Tier 1 suppliers show high reluctance to work with sourcing agents. This mainly derives from the high dependency situation (power imbalance) of Tier 1 suppliers to increase their business and find access to the western export market through sourcing agents [57]. However, receiving orders from sourcing agents will reduce Tier 1 suppliers profits. As such, when retailers opt for mediated sourcing strategies, "direct" governance mechanisms are suggested in order to reduce information asymmetries for social standard implementation [33]. Most importantly, the success of social standard implementation is heavily dependent on developing a trustful and collaborative partnership. This indeed has been proven to be the most promising practice to overcome goal conflicts and barriers in the apparel supply chain $[12,31,122]$.

Standard setters need to reconsider the measures of social standards and develop codes guided by the study's findings. As the study highlights, social standards are highly vulnerable, because they are outcome oriented rather than involving and evaluating the root causes, which have direct impact on the effectiveness of social standards. Therefore, social standards urgently need to incorporate critical performance metrics that go beyond the mere evaluation of a supplier's social performance. This would require the inclusion and evaluation of the buyer's sourcing practice, but also the use of safeguards and social standard implementation uncertainty (e.g., external supply risks) metrics, as these measures impact the social performance of upstream suppliers.

Social standards do not cover the entire supply chain. Social standards do not require strict monitoring requirements beyond Tier 1 suppliers, especially exclude non-export contract manufacturers (subcontractors), which are e.g. processing sub-processes. Mostly, these subcontracting activities remain hidden [113], and it appears to be a fundamental problem in the apparel industry, as embroidery, printing, and washing processes are ritualized tasks to manufacture apparel goods. This is highly critical, especially because non-export Tier $2 \mathrm{CMs}$ are in an economically independent position from the export market and merely obligated to follow local labor law regulations. Therefore, it will remain a charade to assume that social standards are able to regulate socially responsible practices at Tier $2 \mathrm{CMs}$ only by asking Tier 1 suppliers for auditing and monitoring practices. Social standards need to make first and third party audits mandatory to verify subcontractors against the required social standard principles. The audit and monitoring costs need to be carried by apparel retailers, as it is typical that their unfair buying practices cause the need for subcontracting.

Social standards need unannounced audits. The study reveals that social standards are prone to mock compliance, especially due to the social standard's suggestion to announce or semi-announce social audit days. Moreover, the local governments and the third-party 
auditors seem to close their eyes for the greater good of the local community. This issue needs urgent consideration when social standards are developed.

Social standards need to go beyond local wage regulations. In order to increase the income, garment workers explicitly seek Tier 1 suppliers granting high overtime rates. This is mainly attributable to the local labor law regulations, and there is a dire need to reassess the minimum wages in Vietnam and Indonesia. Yet, social standards in the apparel industry merely rely on the minimum wages set by local laws, which are obviously not sufficient to provide a solid living wage $[123,124]$. Although it might seem that governments need to address this problem by reassessing the local minimum wages, social standard developers may review the compensation codes independently.

\subsection{Limitations and Further Research}

If complex globally dispersed supply chains are naturally governed by goal conflicts and information asymmetries, the question arises: which SSCM related compliances practices, such as social certifications, monitoring, and auditing per se, can achieve an improvement in the social sustainability performance? Based on the theoretical contribution of this study, researchers may find guidance to investigate compliance strategies in global supply chains. Further research may provide literature reviews on social standards in global supply chains, with the aim to assess their full scope and answer whether social standards in general are a blessing or a curse. Yet, the study reveals that social standards are part of the problem, which is indeed contradicting prior research [76,81]. However, the study is limited to Vietnam and Indonesia and considers only the apparel sector. The propositions outlined should be tested in other countries and industries characterized by globally dispersed supply chains to evaluate the generalizability of the findings. Researchers should note that the use of agency theory in SSCM disciplines is difficult and highly complex due to the multiple buyer-supplier relations. Therefore, exploring multiple buyer-supplier relationships might affect the quality of analysis, as it may constrain depth in the evaluation of, e.g., dyadic supply chain relationships. Nevertheless, this study serves as a good demonstrative case on how to adopt agency theory to analyze social standards in complex and lengthy multi-tier apparel supply chains. Therefore, as evidence shows, it would be interesting to expand this study and investigate further global textile/apparel supply chains. Additionally, the empirical findings indicate interrelationships between many categories that could be analyzed in particular. For example, hidden actions performed by Tier 1 suppliers showed code-relations to hidden intentions and actions performed by sourcing agents. Thus, opportunistic behaviors that emerge in fashion supply chain relationships seem not to be mutually exclusive and need better understanding in their causality, promising another valuable research direction. Ultimately, other supply chain actors that are critical to the social standard debate are not considered in the study, although they would provide highly valuable insights. Therefore, this study could be complemented by including the views of NGOs, third-party auditors (accreditation agencies), and governments, but most importantly garment workers' perspectives.

Author Contributions: D.K. drafted and wrote the entire manuscript, was responsible for the conceptualization of the paper and the investigation process, developed the research design, and conducted data collection and analysis of the case studies. J.S. supported with necessary resources, assisted during the coding process, and critically revised the manuscript. All authors have read and agreed to the published version of the manuscript.

Funding: The article processing charge was funded by the Baden-Württemberg Ministry of Science, Research, and Culture in the funding program Open Access Publishing.

Conflicts of Interest: The authors declare no conflict of interest. The funders had no role in the design of the study; in the collection, analyses, or interpretation of data; in the writing of the manuscript; or in the decision to publish the results. 


\section{Appendix A}

Table A1. Key findings from case study evidence.

\begin{tabular}{|c|c|c|c|c|c|c|c|c|c|c|c|c|c|c|c|}
\hline $\begin{array}{l}\text { Main Categories } \\
\text { - Subcategories }\end{array}$ & $\begin{array}{l}\text { Supportive Literature } \\
\text { - Novel Findings are Marked with } O\end{array}$ & & & & & Case & Compa & anies $P$ & rovidi & ng Evi & lence & & & & \\
\hline $\begin{array}{l}\text { Goal Conflicts and Information Asymmetries } \\
\text { in Multi-Tier Apparel Supply Chains }\end{array}$ & $\begin{array}{l}\text { Baumann-Pauly, 2014; Busse, 2016; Perry \& } \\
\text { Towers, 2013; Yu, 2008; Ron Masson et al., 2007; } \\
\text { Egels-Zandén \& Lindholm, 2015; Stigzelius \& } \\
\text { Mark-Herbert, 2009: Tachizawa \& Wong, 2014; } \\
\text { Ayuso et al., 2013; Brammer et al., 2011; Foerstl } \\
\text { et al., 2015. }\end{array}$ & Ret & $\begin{array}{c}\text { Int } \\
\text { I }\end{array}$ & $\begin{array}{c}\text { Int } \\
\mathrm{V}\end{array}$ & $\begin{array}{l}\text { Fact } \\
1 \mathrm{~V}\end{array}$ & $\begin{array}{l}\text { Fact } \\
2 \mathrm{~V}\end{array}$ & $\begin{array}{l}\text { Fact } \\
3 \mathrm{~V}\end{array}$ & $\begin{array}{l}\text { Fact } \\
4 \mathrm{~V}\end{array}$ & $\begin{array}{l}\text { Fact } \\
\text { 1I }\end{array}$ & $\begin{array}{l}\text { Fact } \\
\text { 2I }\end{array}$ & $\begin{array}{c}\text { Fact } \\
3 \mathrm{I}\end{array}$ & $\begin{array}{c}\text { Fact } \\
4 \mathrm{I}\end{array}$ & $\begin{array}{c}\text { Fact } \\
5 \mathrm{I}\end{array}$ & $\begin{array}{c}\text { Fact } \\
6 \mathrm{I}\end{array}$ & Total \\
\hline $\begin{array}{l}\text { - Spatial distance: due to their globally } \\
\text { dispersed and complex character, apparel } \\
\text { supply chains naturally suffer from information } \\
\text { asymmetries }\end{array}$ & & $x$ & $x$ & $x$ & $x$ & $x$ & $x$ & $x$ & $x$ & $x$ & $x$ & $x$ & $x$ & $x$ & 13 \\
\hline $\begin{array}{l}\text { - Self-interest: all apparel supply chain actors } \\
\text { are self-interested, predominantly seeking for } \\
\text { profit maximization }\end{array}$ & & $X$ & $X$ & $X$ & $X$ & $X$ & $x$ & $x$ & $X$ & $X$ & $X$ & $X$ & $x$ & $X$ & 13 \\
\hline $\begin{array}{l}\text { - Self-interest: Tier } 1 \text { suppliers reluctantly } \\
\text { contract with sourcing agents }\end{array}$ & $\mathrm{O}$ & & & & $x$ & $x$ & $x$ & $x$ & $x$ & $x$ & $x$ & $x$ & $X$ & $x$ & 10 \\
\hline $\begin{array}{l}\text { - Unfair buying practices: apparel retailers } \\
\text { forecast inaccurate order quantities }\end{array}$ & & $x$ & $x$ & $x$ & $x$ & $x$ & $X$ & $x$ & $x$ & $X$ & $x$ & $x$ & $x$ & $x$ & 13 \\
\hline $\begin{array}{l}\text { Unfair buying practices: internal conflicts } \\
\text { of interest between CR/Compliance managers } \\
\text { and buying/sourcing managers at retailers }\end{array}$ & $\mathrm{O}$ & $x$ & $x$ & $x$ & & & & & & & & & & & 3 \\
\hline
\end{tabular}


Table A1. Cont.

\begin{tabular}{|c|c|c|c|c|c|c|c|c|c|c|c|c|c|c|c|}
\hline $\begin{array}{l}\text { Main Categories } \\
\text { - Subcategories }\end{array}$ & $\begin{array}{l}\text { Supportive Literature } \\
\text { - Novel Findings are Marked with } O\end{array}$ & & & & & Case & Compa & nies $P$ & rovidi & ig Evic & lence & & & & \\
\hline Social standard implementation costs & $\begin{array}{l}\text { Baskaran et al., 2012; Oelze, 2017; Hoang \& } \\
\text { Jones, 2012; Neu et al., 2014; Behnam \& } \\
\text { MacLean, 2011; Ciliberti et al., 2011; Sartor et al., } \\
\text { 2016; Köksal et al., 2018; Fransen, 2011; Locke } \\
\text { et al., 2007; Stigzelius \& Mark-Herbert, 2009; Yu, } \\
\text { 2008; Delbufalo, 2018; Huq et al., 2014 }\end{array}$ & Ret & $\begin{array}{c}\text { Int } \\
\text { I }\end{array}$ & $\begin{array}{c}\text { Int } \\
\text { V }\end{array}$ & $\begin{array}{l}\text { Fact } \\
1 \mathrm{~V}\end{array}$ & $\begin{array}{l}\text { Fact } \\
2 \mathrm{~V}\end{array}$ & $\begin{array}{l}\text { Fact } \\
3 \mathbf{V}\end{array}$ & $\begin{array}{l}\text { Fact } \\
4 \mathrm{~V}\end{array}$ & $\begin{array}{c}\text { Fact } \\
1 \mathrm{I}\end{array}$ & $\begin{array}{c}\text { Fact } \\
2 \mathrm{I}\end{array}$ & $\begin{array}{c}\text { Fact } \\
3 I\end{array}$ & $\begin{array}{c}\text { Fact } \\
4 \mathrm{I}\end{array}$ & $\begin{array}{c}\text { Fact } \\
5 \mathrm{I}\end{array}$ & $\begin{array}{c}\text { Fact } \\
6 \mathrm{I}\end{array}$ & Total \\
\hline $\begin{array}{l}\text { - Apparel retailers are the most isolated } \\
\text { supply chain actors and assume low costs for } \\
\text { ensuring social standard implementation and } \\
\text { compliance in their supply chain }\end{array}$ & $\mathrm{O}$ & & $x$ & $X$ & $X$ & $X$ & & & $X$ & $x$ & $x$ & $x$ & $x$ & & 9 \\
\hline $\begin{array}{l}\text { - Sourcing agents assume high social } \\
\text { standard preparation and monitoring costs. }\end{array}$ & & $X$ & $X$ & $X$ & $X$ & $X$ & $X$ & $X$ & $X$ & $X$ & $X$ & $x$ & $x$ & & 12 \\
\hline $\begin{array}{l}\text { - Tier } 1 \text { suppliers assume high social standard } \\
\text { costs due to multiple certification and expenses } \\
\text { for keeping up with social standard compliance }\end{array}$ & & & $X$ & $X$ & $X$ & $X$ & $\mathrm{X}$ & $X$ & $X$ & $X$ & $X$ & $x$ & $X$ & $x$ & 12 \\
\hline \multicolumn{16}{|l|}{ External risks: } \\
\hline - raw-material delays & $\mathrm{O}$ & $X$ & $x$ & $X$ & $x$ & $X$ & $X$ & $X$ & $X$ & $X$ & $X$ & $x$ & $X$ & $x$ & 13 \\
\hline - local and international market competition & & & $X$ & $X$ & & $X$ & & $X$ & $X$ & $X$ & & $X$ & $X$ & $X$ & 9 \\
\hline - low governmental enforcement & & & & $X$ & & $X$ & & & $X$ & $X$ & & & $X$ & $X$ & 6 \\
\hline \multicolumn{16}{|l|}{ internal risks: } \\
\hline $\begin{array}{l}\text { - misalignment between western-based } \\
\text { standard requirements and local culture of } \\
\text { suppliers }\end{array}$ & $\mathrm{O}$ & $X$ & $X$ & $X$ & $X$ & $X$ & $x$ & $X$ & $x$ & $X$ & $x$ & $x$ & $x$ & $x$ & 13 \\
\hline $\begin{array}{l}\text { - flawed production capacity planning of } \\
\text { suppliers }\end{array}$ & & & $x$ & $x$ & $x$ & $x$ & & $x$ & & & & & & & 7 \\
\hline - production inefficiencies at suppliers & & & $x$ & $x$ & & $x$ & & & $x$ & & & & $x$ & & 5 \\
\hline
\end{tabular}


Table A1. Cont.

\begin{tabular}{|c|c|c|c|c|c|c|c|c|c|c|c|c|c|c|c|}
\hline $\begin{array}{l}\text { Main Categories } \\
\text { - Subcategories }\end{array}$ & $\begin{array}{l}\text { Supportive Literature } \\
\text { - Novel Findings are Marked with } O\end{array}$ & & & & & Case & Compa & Inies $\mathrm{F}$ & rovidi & $\lg$ Evi & lence & & & & \\
\hline $\begin{array}{l}\text { Risk attitude towards social standard } \\
\text { implementation }\end{array}$ & $\begin{array}{l}\text { Jiang, 2009; Hajmohammad \& Vachon, 2016; } \\
\text { Busse, 2016; Köksal et al., 2017; Shafiq et al., } \\
\text { 2017; Bebbington \& Thomson, 2007; Gilbert } \\
\text { et al., 2011; Freise \& Seuring, 2015; Hoejmose } \\
\text { et al., 2014; Short et al., 2016; Gualandris et al., } \\
\text { 2015; Grimm et al., 2016; Neu et al., 2014; } \\
\text { Klassen \& Vereecke, 2012; Perry et al., 2015; } \\
\text { Delbufalo, } 2018\end{array}$ & Ret & Int & $\begin{array}{c}\text { Int } \\
\text { V }\end{array}$ & $\begin{array}{l}\text { Fact } \\
1 \mathrm{~V}\end{array}$ & $\begin{array}{l}\text { Fact } \\
2 \mathrm{~V}\end{array}$ & $\begin{array}{l}\text { Fact } \\
3 \mathrm{~V}\end{array}$ & $\begin{array}{l}\text { Fact } \\
4 \mathrm{~V}\end{array}$ & $\begin{array}{c}\text { Fact } \\
1 \mathrm{II}\end{array}$ & $\begin{array}{c}\text { Fact } \\
\text { 2I }\end{array}$ & $\begin{array}{c}\text { Fact } \\
3 I\end{array}$ & $\begin{array}{c}\text { Fact } \\
4 \mathrm{I}\end{array}$ & $\begin{array}{c}\text { Fact } \\
5 \mathrm{I}\end{array}$ & $\begin{array}{c}\text { Fact } \\
6 \mathrm{I}\end{array}$ & Total \\
\hline - Apparel retailers-high & & $x$ & $x$ & $x$ & $x$ & $x$ & & & & & & $x$ & $x$ & $x$ & 8 \\
\hline - Sourcing agents—high & & & $x$ & $x$ & & $x$ & & & & & & & $x$ & $x$ & 5 \\
\hline - Tier 1 suppliers-high & & $x$ & $x$ & $x$ & $x$ & $x$ & $x$ & $x$ & $x$ & $x$ & $x$ & $x$ & $x$ & $x$ & 13 \\
\hline - Tier 2 CM-low & $\mathrm{O}$ & & $x$ & $x$ & & $x$ & & & & & & & $x$ & $x$ & 5 \\
\hline $\begin{array}{l}\text { Risk acceptance for social standard } \\
\text { implementation }\end{array}$ & & Ret & Int & $\begin{array}{c}\text { Int } \\
\text { V }\end{array}$ & $\begin{array}{l}\text { Fact } \\
1 \mathrm{~V}\end{array}$ & $\begin{array}{l}\text { Fact } \\
2 \mathrm{~V}\end{array}$ & $\begin{array}{l}\text { Fact } \\
3 \mathrm{~V}\end{array}$ & $\begin{array}{l}\text { Fact } \\
4 \mathrm{~V}\end{array}$ & $\begin{array}{c}\text { Fact } \\
\text { 1I }\end{array}$ & $\begin{array}{c}\text { Fact } \\
\text { 2I }\end{array}$ & $\begin{array}{c}\text { Fact } \\
3 I\end{array}$ & $\begin{array}{c}\text { Fact } \\
4 \mathrm{I}\end{array}$ & $\begin{array}{c}\text { Fact } \\
5 \mathrm{I}\end{array}$ & $\begin{array}{c}\text { Fact } \\
6 \mathrm{I}\end{array}$ & Total \\
\hline - Sourcing agents-high & $\mathrm{O}$ & $x$ & $x$ & $x$ & $x$ & $x$ & $x$ & & $x$ & $x$ & $x$ & $x$ & $x$ & $x$ & 12 \\
\hline - Tier 1 suppliers-high & $\mathrm{O}$ & & $x$ & $x$ & $x$ & $x$ & $x$ & $x$ & $x$ & $x$ & $x$ & $x$ & $x$ & $x$ & 13 \\
\hline - $\quad$ Tier $2 \mathrm{CM}-$ low & $\mathrm{O}$ & & $x$ & $x$ & & $x$ & & & $x$ & & & & $x$ & $x$ & 6 \\
\hline $\begin{array}{l}\text { Safeguards for social standard } \\
\text { implementation }\end{array}$ & $\begin{array}{l}\text { Klassen \& Vereecke, 2012; Emmelhainz \& } \\
\text { Adams, 1999; Perry et al., 2013; Delbufalo \& } \\
\text { Bastl, 2018; Huq et al., 2014; Yu, 2008; Stigzelius } \\
\text { \& Mark-Herbert, 2009; Pedersen \& Andersen, } \\
\text { 2006; Walker \& Jones, } 2012\end{array}$ & Ret & Int & $\begin{array}{c}\text { Int } \\
\text { V }\end{array}$ & $\begin{array}{l}\text { Fact } \\
1 \mathrm{~V}\end{array}$ & $\begin{array}{l}\text { Fact } \\
2 \mathrm{~V}\end{array}$ & $\begin{array}{l}\text { Fact } \\
3 \mathrm{~V}\end{array}$ & $\begin{array}{c}\text { Fact } \\
4 \mathrm{~V}\end{array}$ & $\begin{array}{c}\text { Fact } \\
\text { 1I }\end{array}$ & $\begin{array}{c}\text { Fact } \\
2 \mathrm{I}\end{array}$ & $\begin{array}{c}\text { Fact } \\
3 I\end{array}$ & $\begin{array}{c}\text { Fact } \\
4 \mathrm{I}\end{array}$ & $\begin{array}{c}\text { Fact } \\
5 \mathrm{I}\end{array}$ & $\begin{array}{c}\text { Fact } \\
6 \mathrm{I}\end{array}$ & Total \\
\hline \multicolumn{16}{|l|}{ Incentives and sanctions in use: } \\
\hline $\begin{array}{l}\text { - Reputation effects for suppliers (e.g., } \\
\text { attracting new buyers) }\end{array}$ & & $x$ & $x$ & $x$ & $x$ & $x$ & $x$ & $x$ & $x$ & $x$ & $x$ & $x$ & $x$ & $x$ & 13 \\
\hline $\begin{array}{l}\text { - Suppliers hope to attract big order } \\
\text { placements }\end{array}$ & & & $x$ & $x$ & $x$ & $x$ & $x$ & $x$ & $x$ & $x$ & $x$ & $x$ & $x$ & $x$ & 12 \\
\hline - Suppliers risk termination of future orders & & & $x$ & $x$ & $x$ & $X$ & $x$ & $x$ & $x$ & $x$ & $x$ & $x$ & $x$ & & 12 \\
\hline
\end{tabular}


Table A1. Cont.

\begin{tabular}{|c|c|c|c|c|c|c|c|c|c|c|c|c|c|c|c|}
\hline $\begin{array}{l}\text { Main Categories } \\
\text { - Subcategories }\end{array}$ & $\begin{array}{c}\text { Supportive Literature } \\
\text { - Novel Findings are Marked with } O\end{array}$ & & & & & Case & Comp & anies $\mathrm{P}$ & rovidi & ng Evi & dence & & & & \\
\hline \multicolumn{16}{|l|}{ Lack of incentives and sanctions: } \\
\hline - No price premiums offered by buyers & & & $x$ & $x$ & $x$ & $x$ & $x$ & $x$ & $x$ & $x$ & $x$ & $x$ & $x$ & $x$ & 12 \\
\hline - No cost sharing offered by buyers & & & $x$ & $x$ & $x$ & $X$ & $x$ & $x$ & $X$ & $x$ & $x$ & $X$ & $x$ & $x$ & 12 \\
\hline $\begin{array}{l}\text { - No guarantee for continuous orders offered } \\
\text { by buyers }\end{array}$ & & & $x$ & $x$ & $x$ & $x$ & $x$ & $x$ & $x$ & $x$ & $x$ & $x$ & $x$ & $x$ & 12 \\
\hline - No risk for termination of a running order & $\mathrm{O}$ & $x$ & $x$ & $x$ & $x$ & $X$ & $x$ & $x$ & $x$ & $x$ & $x$ & $x$ & & & 11 \\
\hline Predominant social standard failures & $\begin{array}{l}\text { Pruett, 2005; FWF, 2015, 2018; Better Work } \\
\text { Vietnam, 2017; Better Work Indonesia, 2017: } \\
\text { Egels-Zandén \& Lindholm, 2015; Huq et al., } \\
2014\end{array}$ & Ret & Int & $\begin{array}{c}\text { Int } \\
\text { V }\end{array}$ & $\begin{array}{l}\text { Fact } \\
1 \mathrm{~V}\end{array}$ & $\begin{array}{l}\text { Fact } \\
2 \mathrm{~V}\end{array}$ & $\begin{array}{l}\text { Fact } \\
3 \mathrm{~V}\end{array}$ & $\begin{array}{l}\text { Fact } \\
4 \mathrm{~V}\end{array}$ & $\begin{array}{c}\text { Fact } \\
\text { 1I }\end{array}$ & $\begin{array}{c}\text { Fact } \\
\text { 2I }\end{array}$ & $\begin{array}{c}\text { Fact } \\
\text { 3I }\end{array}$ & $\begin{array}{c}\text { Fact } \\
4 \mathrm{I}\end{array}$ & $\begin{array}{c}\text { Fact } \\
5 \mathrm{I}\end{array}$ & $\begin{array}{c}\text { Fact } \\
6 \mathrm{I}\end{array}$ & Total \\
\hline - Excessive overtime & & $x$ & $x$ & $x$ & $X$ & $X$ & $x$ & $X$ & $x$ & $x$ & $x$ & $X$ & $x$ & $x$ & 13 \\
\hline $\begin{array}{l}\text { - Subcontracting (neglected social audits and } \\
\text { monitoring) }\end{array}$ & & & $x$ & $x$ & $x$ & $x$ & $x$ & $x$ & $x$ & $x$ & $x$ & $x$ & $x$ & $x$ & 12 \\
\hline - Mock compliance & & & $x$ & $x$ & $x$ & $x$ & $x$ & $x$ & $x$ & $x$ & $x$ & $x$ & $x$ & $x$ & 12 \\
\hline - Health and safety & & & $x$ & $X$ & $x$ & $X$ & $x$ & $x$ & $x$ & $x$ & $x$ & $x$ & $x$ & & 11 \\
\hline - Compensation/wages and benefits & & & $x$ & & $x$ & $x$ & $x$ & & $x$ & $x$ & $x$ & $x$ & $x$ & $x$ & 10 \\
\hline - Trainings for production workers & & & & & $x$ & $x$ & $x$ & $x$ & $x$ & $x$ & $x$ & $x$ & $x$ & $x$ & 10 \\
\hline $\begin{array}{l}\text { Opportunistic behaviors of upstream supply } \\
\text { chain actors }\end{array}$ & $\begin{array}{l}\text { Pruett, 2005; Delbufalo \& Bastl, 2018; Delbufalo, } \\
\text { 2018; Pedersen \& Andersen, 2006; Ciliberti et al., } \\
\text { 2011, Mares, 2010; Huq et al., } 2014\end{array}$ & Ret & Int & $\begin{array}{c}\text { Int } \\
\text { V }\end{array}$ & $\begin{array}{l}\text { Fact } \\
1 \mathrm{~V}\end{array}$ & $\begin{array}{l}\text { Fact } \\
2 \mathrm{~V}\end{array}$ & $\begin{array}{l}\text { Fact } \\
3 \mathrm{~V}\end{array}$ & $\begin{array}{c}\text { Fact } \\
4 \mathrm{~V}\end{array}$ & $\begin{array}{c}\text { Fact } \\
\text { 1I }\end{array}$ & $\begin{array}{c}\text { Fact } \\
2 \text { I }\end{array}$ & $\begin{array}{c}\text { Fact } \\
\text { 3I }\end{array}$ & $\begin{array}{c}\text { Fact } \\
4 \mathrm{I}\end{array}$ & $\begin{array}{c}\text { Fact } \\
5 \mathrm{I}\end{array}$ & $\begin{array}{c}\text { Fact } \\
6 \mathrm{I}\end{array}$ & Total \\
\hline \multicolumn{16}{|l|}{ Sourcing Agents: } \\
\hline $\begin{array}{l}\text { - Hidden characteristics: in order to win the } \\
\text { contract with the retailer, merchandise } \\
\text { managers knowingly threaten social standards } \\
\text { by offering/accepting deficient prices and } \\
\text { lead-times based on the misrepresentation of } \\
\text { supplier base capabilities. }\end{array}$ & $\mathrm{O}$ & & $x$ & $x$ & $x$ & $x$ & $x$ & $x$ & $x$ & $x$ & $x$ & $x$ & $x$ & & 11 \\
\hline
\end{tabular}


Table A1. Cont.

\begin{tabular}{|c|c|c|c|c|c|c|c|c|c|c|c|c|c|c|}
\hline $\begin{array}{l}\text { Main Categories } \\
\text { - Subcategories }\end{array}$ & $\begin{array}{l}\text { Supportive Literature } \\
\text { - Novel Findings are Marked with } O\end{array}$ & & & & Cas & om & nies & ovic & $\mathrm{g}$ Ex & ence & & & & \\
\hline $\begin{array}{l}\text { - Hidden intentions: intentional and unfair } \\
\text { subcontracting practices to Tier } 2 \mathrm{CMs} \text {, in order } \\
\text { to meet the price and lead-time targets }\end{array}$ & $\mathrm{O}$ & $x$ & $X$ & $x$ & $X$ & $x$ & $x$ & $X$ & $x$ & $x$ & $X$ & $x$ & $x$ & 12 \\
\hline $\begin{array}{l}\text { Hidden actions: in order to keep a good } \\
\text { lead-time performance, mediated information } \\
\text { to suppliers is modified or restrained. }\end{array}$ & $\mathrm{O}$ & $x$ & $X$ & $x$ & $X$ & $x$ & $x$ & $x$ & $x$ & $x$ & $x$ & $x$ & $x$ & 12 \\
\hline \multicolumn{15}{|l|}{ Tier 1 Suppliers: } \\
\hline $\begin{array}{l}\text { - Hidden characteristic: in order to win the } \\
\text { contract with the buyer (retailers or sourcing } \\
\text { agents), merchandise managers deliberately } \\
\text { threaten social standards by offering/accepting } \\
\text { deficient prices, lead-times, and unexpected } \\
\text { orders based on too optimistic production } \\
\text { planning managers who calculate flawed } \\
\text { capacities. }\end{array}$ & & $X$ & $x$ & $x$ & $x$ & $x$ & $x$ & $x$ & $x$ & $x$ & $x$ & $x$ & & 11 \\
\hline $\begin{array}{l}\text { - Hidden action: in order to save costs, social } \\
\text { audits and monitoring systems at subcontr- } \\
\text { actors are neglected or even not performed }\end{array}$ & $\mathrm{O}$ & $x$ & $X$ & $x$ & $X$ & $x$ & $x$ & $x$ & $x$ & $x$ & $x$ & $x$ & $x$ & 12 \\
\hline $\begin{array}{l}\text { - Hidden action: in order to save costs and } \\
\text { pretend "good" compliance for keeping the } \\
\text { relationship with buyers, suppliers practice } \\
\text { mock compliance. }\end{array}$ & & $x$ & $x$ & $x$ & $x$ & $x$ & $x$ & $x$ & $x$ & $X$ & $x$ & $x$ & $x$ & 12 \\
\hline \multicolumn{15}{|l|}{ Tier 2 Supplier (CM/Subcontractor): } \\
\hline $\begin{array}{l}\text { - No opportunistic behavior performed } \\
\text { because of no contractual social standard } \\
\text { obligation }\end{array}$ & $\mathrm{O}$ & $x$ & $x$ & & $x$ & & & $x$ & & & & $x$ & $x$ & 6 \\
\hline
\end{tabular}




\section{References}

1. Gualandris, J.; Klassen, R.D.; Vachon, S.; Kalchschmidt, M. Sustainable Evaluation and Verification in Supply Chains: Aligning and Leveraging Accountability to Stakeholders. J. Oper. Manag. 2015, 38, 1-13. [CrossRef]

2. Neu, D.; Rahaman, A.S.; Everett, J. Accounting and Sweatshops: Enabling Coordination and Control in Low-Price Apparel Production Chains. Contemp. Acc. Res. 2014, 31, 322-346. [CrossRef]

3. Freise, M.; Seuring, S. Social and Environmental Risk Management in Supply Chains: A Survey in the Clothing Industry. Logist. Res. 2015, 8, 1-12. [CrossRef]

4. Hajmohammad, S.; Vachon, S. Mitigation, Avoidance, or Acceptance? Managing Supplier Sustainability Risk. J. Supply Chain Manag. 2016, 52, 48-65. [CrossRef]

5. Yawar, S.A.; Seuring, S. Management of Social Issues in Supply Chains: A Literature Review Exploring Social Issues, Actions and Performance Outcomes. J. Bus. Ethics 2015, 141, 621-643. [CrossRef]

6. Bebbington, J.; Larrinaga, C. Accounting and Sustainable Development: An Exploration. Account. Organ. Soc. 2014, 39, 395-413. [CrossRef]

7. Gilbert, D.U.; Rasche, A.; Waddock, S. Accountability in a Global Economy: The Emergence of International Accountability Standards. Bus. Ethics Q. 2011, 21, 23-44. [CrossRef]

8. Turker, D.; Altuntas, C. Sustainable Supply Chain Management in the Fast Fashion Industry: An Analysis of Corporate Reports. Eur. Manag. J. 2014, 32, 837-849. [CrossRef]

9. Allwood, J. Well Dressed?: The Present and Future Sustainability of Clothing and Textiles in the United Kingdom; University of Cambridge, Institute for Manufacturing: Cambridge, UK, 2006; ISBN 978-1-902546-52-0.

10. Mares, R. The Limits of Supply Chain Responsibility: A Critical Analysis of Corporate Responsibility Instruments. Nord. J. Int. Law 2010, 79, 193-244. [CrossRef]

11. Masson, R.; Iosif, L.; MacKerron, G.; Fernie, J. Managing Complexity in Agile Global Fashion Industry Supply Chains. Int. J. Logist. Manag. 2007, 18, 238-254. [CrossRef]

12. Perry, P.; Towers, N. Conceptual Framework DevelopmentCSR Implementation in Fashion Supply Chains. Int. J. Phys. Distrib. Logist. Manag. 2013, 43, 478-501. [CrossRef]

13. European Commission. European Commission Study on the Responsible Management of the Supply Chain in the Garment Sector-International Cooperation and Development. Available online: https:/ / ec.europa.eu/europeaid/study-responsiblemanagement-supply-chain-garment-sector_en (accessed on 13 October 2018).

14. Anner, M. Labor Control Regimes and Worker Resistance in Global Supply Chains. Labor Hist. 2015, 56, 292. [CrossRef]

15. O'Rourke, D. Outsourcing Regulation: Analyzing Nongovernmental Systems of Labor Standards and Monitoring. Policy Stud. J. 2003, 31, 1-29. [CrossRef]

16. O'Rourke, D. Multi-Stakeholder Regulation: Privatizing or Socializing Global Labor Standards? World Dev. 2006, 34, 899-918. [CrossRef]

17. Sartor, M.; Orzes, G.; Di Mauro, C.; Ebrahimpour, M.; Nassimbeni, G. The SA8000 Social Certification Standard: Literature Review and Theory-Based Research Agenda. Int. J. Prod. Econ. 2016, 175, 164-181. [CrossRef]

18. European Center for Constitutional and Human Rights. Rana Plaza: Zertifikate in der Textilindustrie. Available online: https://www.ecchr.eu/fall/mehr-show-als-sicherheit-zertifikate-in-der-textilindustrie/ (accessed on 19 September 2019).

19. Clean Clothes Campaign; SOMO. Fatal Fashion-Analysis of Recent Factory Fires in Pakistan and Bangladesh. Available online: https:/ / cleanclothes.org/file-repository/resources-publications-fatal-fashion.pdf/view (accessed on 8 October 2019).

20. Terwindt, C.; Saage-Maass, M. Liability of Social Auditors in the Textile Industry; ECCHR: Berlin, Germany, 2016; p. 17. Available online: https://www.ecchr.eu/en/publication/liability-of-social-auditors-in-the-textile-industry/ (accessed on 11 October 2018).

21. Girit, S.; BBC News. Zara Shoppers Find Labour Complaints inside Clothes. Available online: https://www.bbc.com/news / world-europe-41981509 (accessed on 15 November 2017).

22. Guilbert, K. Reuters. H\&M Accused of Failing to Ensure Fair Wages for Global Factory Workers. Available online: https: / / www.reuters.com/article/us-workers-garment-abuse-idUSKCN1M41GR (accessed on 20 September 2019).

23. Pruett, D. Looking for a Quick Fix - How Weak Social Auditing Is Keeping Workers in Sweatshops; Clean Clothes Campaign: Amsterdam, The Netherlands, 2005.

24. Volodzko, D. Bangladesh Is Burning and Sweatshops are the Fuel. Available online: https://www.forbes.com/sites/ davidvolodzko/2019/03/05/bangladesh-and-the-fire-next-time/ (accessed on 19 September 2019).

25. Delbufalo, E. Agency Theory and Sustainability in the Global Supply Chain; Springer: Berlin/Heidelberg, Germany, 2018; ISBN 978-3-319-72793-6.

26. Andersen, M.; Pedersen, E. Safeguarding Corporate Social Responsibility (CSR) in Global Supply Chains: How Codes of Conduct Are Managed in Buyer-supplier Relationships. J. Public Aff. 2006, 6, 228-240.

27. Ayuso, S.; Colomé, R.; Roca, M. SMEs as "Transmitters" of CSR Requirements in the Supply Chain. Supply Chain Manag. 2013, 18, 497-508. [CrossRef]

28. Grimm, J.H.; Hofstetter, J.S.; Sarkis, J. Exploring Sub-Suppliers' Compliance with Corporate Sustainability Standards. J. Clean. Prod. 2016, 112, 1971-1984. [CrossRef] 
29. Nakamba, C.C.; Chan, P.W.; Sharmina, M. How Does Social Sustainability Feature in Studies of Supply Chain Management? A Review and Research Agenda. Supply Chain Manag. 2017, 22, 522-541. [CrossRef]

30. Oelze, N.; Gruchmann, T.; Brandenburg, M. Motivating Factors for Implementing Apparel Certification Schemes-A Sustainable Supply Chain Management Perspective. Sustainability 2020, 12, 4823. [CrossRef]

31. Köksal, D.; Strähle, J.; Müller, M.; Freise, M. Social Sustainable Supply Chain Management in the Textile and Apparel Industry-A Literature Review. Sustainability 2017, 9, 100. [CrossRef]

32. Touboulic, A.; Walker, H. Theories in Sustainable Supply Chain Management: A Structured Literature Review. Int. J. Phys. Distrib. Logist. Manag. 2015, 45, 16-42. [CrossRef]

33. Tachizawa, E.M.; Yew Wong, C. Towards a Theory of Multi-Tier Sustainable Supply Chains: A Systematic Literature Review. Supply Chain Manag. 2014, 19, 643-663. [CrossRef]

34. Wilhelm, M.M.; Blome, C.; Bhakoo, V.; Paulraj, A. Sustainability in Multi-Tier Supply Chains: Understanding the Double Agency Role of the First-Tier Supplier. J. Oper. Manag. 2016, 41, 42-60. [CrossRef]

35. Yawar, S.A.; Seuring, S. The Role of Supplier Development in Managing Social and Societal Issues in Supply Chains. J. Clean. Prod. 2018, 182, 227-237. [CrossRef]

36. Fayezi, S.; O'Loughlin, A.; Zutshi, A. Agency Theory and Supply Chain Management: A Structured Literature Review. Supply Chain Manag. 2012, 17, 556-570. [CrossRef]

37. Quarshie, A.M.; Salmi, A.; Leuschner, R. Sustainability and Corporate Social Responsibility in Supply Chains: The State of Research in Supply Chain Management and Business Ethics Journals. J. Purch. Supply Manag. 2015. [CrossRef]

38. Awaysheh, A.; Klassen, R.D. The Impact of Supply Chain Structure on the Use of Supplier Socially Responsible Practices. Int. J. Oper. Prod Manag. 2010, 30, 1246-1268. [CrossRef]

39. Huq, F.A.; Chowdhury, I.N.; Klassen, R.D. Social Management Capabilities of Multinational Buying Firms and Their Emerging Market Suppliers: An Exploratory Study of the Clothing Industry. J. Oper. Manag. 2016, 46, 19-37. [CrossRef]

40. Seuring, S.; Müller, M. From a Literature Review to a Conceptual Framework for Sustainable Supply Chain Management. J. Clean. Prod. 2008, 16, 1699-1710. [CrossRef]

41. Brammer, S.; Hoejmose, S.; Millington, A. Managing Sustainable Global Supply Chain: Framework and Best Practices; Network for Business Sustainability: 2011. Available online: https://researchportal.bath.ac.uk/en/publications/managing-sustainableglobal-supply-chain-framework-and-best-pract (accessed on 7 December 2018).

42. Foerstl, K.; Azadegan, A.; Leppelt, T.; Hartmann, E. Drivers of Supplier Sustainability: Moving Beyond Compliance to Commitment. J. Supply Chain Manag. 2015, 51, 67-92. [CrossRef]

43. Whipple, J.M.; Roh, J. Agency Theory and Quality Fade in Buyer-supplier Relationships. Int. J. Logist. Manag. 2010, 21, 338-352. [CrossRef]

44. Business Social Compliance Initiative. Amfori BSCI System Manual_ENG.Pdf. Available online: https://www.amfori.org/sites / default/files/amfori\%20BSCI\%20System\%20Manual_ENG.pdf (accessed on 22 December 2018).

45. Van Huijstee, M. Making Private Standards Work for You: A Guide to Private Standards in the Garments, Footwear and Furniture Sectors. Available online: https: / / www.somo.nl/making-private-standards-work-for-you-a-guide-to-private-standards-inthe-garments-footwear-and-furniture-sectors / (accessed on 14 October 2018).

46. SA8000 Guidance Document for Social Accountability 8000 (SA8000®:2014). Available online: https://sa-intl.org/wp-content/ uploads/2020/02/SA8000-2014-Guidance-Document.pdf (accessed on 10 December 2018).

47. Waste and Resources Action Programme. Factory Handbook 2014. Available online: http://www.wrapcompliance.org/upload/ Documents / 2014\%20Factory\%20Handbook\%20v2.pdf (accessed on 22 December 2018).

48. Carter, C.R.; Rogers, D.S. A Framework of Sustainable Supply Chain Management: Moving toward New Theory. Int. J. Phys. Distrib. Logist. Manag. 2008, 38, 360-387. [CrossRef]

49. Meixell, M.J.; Luoma, P. Stakeholder Pressure in Sustainable Supply Chain Management: A Systematic Review. Int. J. Phys. Distrib. Logist. Manag. 2015, 45, 69-89. [CrossRef]

50. Park-Poaps, H.; Rees, K. Stakeholder Forces of Socially Responsible Supply Chain Management Orientation. J. Bus. Ethics 2010, 92, 305-322. [CrossRef]

51. Hoejmose, S.U.; Roehrich, J.K.; Grosvold, J. Is Doing More Doing Better? The Relationship between Responsible Supply Chain Management and Corporate Reputation. Ind. Mark. Manag. 2014, 43, 77-90. [CrossRef]

52. International Trade Center. Sustainability Map. Available online: https://sustainabilitymap.org/standards (accessed on 31 October 2018).

53. Behnam, M.; MacLean, T.L. Where Is the Accountability in International Accountability Standards? A Decoupling Perspective. Bus. Ethics Q. 2011, 21, 45-72. [CrossRef]

54. Mena, C.; Humphries, A.; Choi, T.Y. Toward a Theory of Multi-Tier Supply Chain Management. J. Supply Chain Manag. 2013, 49, 58-77. [CrossRef]

55. Wiese, A.; Toporowski, W. CSR Failures in Food Supply Chains-An Agency Perspective. Br. Food J. 2013, 115, 92-107. [CrossRef]

56. Andersen, M.; Skjoett Larsen, T. Corporate Social Responsibility in Global Supply Chains. Supply Chain Manag. 2009, 14, 75-86. [CrossRef]

57. Köksal, D.; Strähle, J.; Müller, M. Social Sustainability in Apparel Supply Chains-The Role of the Sourcing Intermediary in a Developing Country. Sustainability 2018, 10, 1039. [CrossRef] 
58. Cook, C.N. The Role of Sourcing Agents in Global Apparel Supply Chains: An Exploratory Study. Ph.D. Thesis, Kansas State University, Manhattan. KS, USA, 2010.

59. Purvis, L.; Naim, M.M.; Towill, D. Intermediation in Agile Global Fashion Supply Chains. Int. J. Eng. Sci. Technol. 2013, 5, 33-48. [CrossRef]

60. Eisenhardt, K.M. Agency Theory: An Assessment and Review. Acad. Manag. Rev. 1989, 14, 57-74. [CrossRef]

61. Bergen, M.; Dutta, S.; Walker, O.C., Jr. Agency Relationships in Marketing: A Review of the Implications and Applications of Agency and Related. J. Mark. 1992, 56, 1-24. [CrossRef]

62. Jensen, C.; Meckling, H. Theory of the Firm: Managerial Behavior, Agency Costs and Ownership Structure. J. Financ. Econ. 1976, 3, 305-360. [CrossRef]

63. Perrow, C. Economic Theories of Organization. Theor. Soc. 1986, 15, 11-45. [CrossRef]

64. Göbel, E. Neue Institutionenökonomik: Konzeption Und Betriebswirtschaftliche Anwendungen. In Grundwissen der Ökonomik: Betriebswirtschaftslehre; Lucius \& Lucius: Stuttgart, Germany, 2002; ISBN 978-3-8252-2235-2.

65. Schölermann, S. Eine Institutionenökonomische Analyse Der "Kooperations-Beratung"; Arbeitspapiere des Instituts für Genossenschaftswesen der Westfälischen Wilhelms-Universität Münster: Münster, Germany, 2003.

66. Broens, M. Die Auslagerung kommunaler Beschaffungsaufgaben als Alternative zur internen Durchführung: Entwicklung eines multitheoretischen Entscheidungsrahmens. In Supply Management Research: Aktuelle Forschungsergebnisse 2015; Bogaschewsky, R., Eßig, M., Lasch, R., Stölzle, W., Eds.; Springer: Wiesbaden, Germany, 2016; pp. 3-35. ISBN 978-3-658-08809-5.

67. Saam, N.J. Asymmetry in Information versus Asymmetry in Power: Implicit Assumptions of Agency Theory? J. Socio-Econ. 2007, 36, 825-840. [CrossRef]

68. Arrow, K. The Economics of Agency; Harvard Business School Press: Boston, MA, USA, 1985; p. 33.

69. Shapiro, S.P. Agency Theory. Annu. Rev. Sociol. 2005, 31, 263-284. [CrossRef]

70. Zu, X.; Kaynak, H. An Agency Theory Perspective on Supply Chain Quality Management. Int. J. Oper. Prod Manag. 2012, 32, 423-446. [CrossRef]

71. Rungtusanatham, M.; Rabinovich, E.; Ashenbaum, B.; Wallin, C. Vendor-Owned Inventory Management Arrangements in Retail: An Agency Theory Perspective. J. Bus. Logist. 2007, 28, 111-135. [CrossRef]

72. Hendry, J. The Principal's Other Problems: Honest Incompetence and the Specification of Objectives. Acad. Manag. Rev. 2002, 27, 98-113. [CrossRef]

73. Spremann, V.K. Asymmetrische Information. Z. Betr. 1990, 60, 561-586.

74. Hess, T. Implikationen der Prinzipal-Agent-Theorie für das Management von Unternehmensnetzwerken; Universität Göttingen: Göttingen, Germany, 1999; p. 25.

75. Halldórsson, Á.; Kotzab, H.; Hsuan, J. Complementary Theories to Supply Chain Management Revisited-From Borrowing Theories to Theorizing. Supply Chain Manag. 2015, 20, 574-586. [CrossRef]

76. Ciliberti, F.; de Haan, J.; de Groot, G.; Pontrandolfo, P. CSR Codes and the Principal-Agent Problem in Supply Chains: Four Case Studies. J. Clean. Prod. 2011, 19, 885-894. [CrossRef]

77. Delbufalo, E.; Bastl, M. Multi-Principal Collaboration and Supplier's Compliance with Codes-of-Conduct. Int. J. Logist. Manag. 2018, 29, 1237-1254. [CrossRef]

78. Hornibrook, S. Goals and Incentives in Supply Chain Organisations; University of Kent: Kent, UK, $2007 ;$ p. 40.

79. Emmelhainz, M.A.; Adams, R.J. The Apparel Industry Response to "Sweatshop" Concerns: A Review and Analysis of Codes of Conduct. J. Supply Chain Manag. 1999, 35, 51. [CrossRef]

80. Huq, F.A.; Stevenson, M.; Zorzini, M. Social Sustainability in Developing Country SuppliersAn Exploratory Study in the Ready Made Garments Industry of Bangladesh. Int. J. Oper. Prod. Manag. 2014, 34, 610.

81. Ciliberti, F.; de Groot, G.; de Haan, J.; Pontrandolfo, P. Codes to Coordinate Supply Chains: SMEs' Experiences with SA8000. Supply Chain Manag. 2009, 14, 117-127. [CrossRef]

82. Busse, C. Doing Well by Doing Good? The Self-Interest of Buying Firms and Sustainable Supply Chain Management. J. Supply Chain Manag. 2016, 52, 28-47. [CrossRef]

83. Foerstl, K.; Reuter, C.; Hartmann, E.; Blome, C. Managing Supplier Sustainability Risks in a Dynamically Changing EnvironmentSustainable Supplier Management in the Chemical Industry. J. Purch. Supply Manag. 2010, 16, 118-130. [CrossRef]

84. Stigzelius, I.; Mark-Herbert, C. Tailoring Corporate Responsibility to Suppliers: Managing SA8000 in Indian Garment Manufacturing. Scand. J. Manag. 2009, 25, 46-56. [CrossRef]

85. Choi, T.Y.; Krause, D.R. The Supply Base and Its Complexity: Implications for Transaction Costs, Risks, Responsiveness, and Innovation. J. Oper. Manag. 2006, 24, 637-652. [CrossRef]

86. Giannakis, M.; Papadopoulos, T. Supply Chain Sustainability: A Risk Management Approach. Int. J. Prod. Econ. 2016, 171, 455-470. [CrossRef]

87. Keow Cheng, S.; Hon Kam, B. A Conceptual Framework for Analysing Risk in Supply Networks. J. Enterp. Inf. Manag. 2008, 21, 345-360. [CrossRef]

88. Zsidisin, G.A.; Ellram, L.M. An Agency Theory Investigation of Supply Risk M Anagement. J. Supply Chain Manag. 2003, 39, 15-27. [CrossRef]

89. Yu, X. Impacts of Corporate Code of Conduct on Labor Standards: A Case Study of Reebok's Athletic Footwear Supplier Factory in China. J. Bus. Ethics 2008, 81, 513-529. [CrossRef] 
90. Porteous, A.H.; Rammohan, S.V.; Lee, H.L. Carrots or Sticks? Improving Social and Environmental Compliance at Suppliers Through Incentives and Penalties. Prod. Oper. Manag. 2015, 24, 1402-1413. [CrossRef]

91. Eisenhardt, K.M.; Graebner, M.E. Theory Building from Cases: Opportunities and Challenges. Acad. Manag. J. 2007, 50, 25-32. [CrossRef]

92. Ridder, H.-G. Case Study Research—Sozialwissenschaftliche Forschungsmethoden; Rainer Hampp Verlag: Munich, Germany, 2016; Volume 12, ISBN 978-3-95710-175-4.

93. Yin, R.K. Case Study Research: Design and Methods; SAGE: Thousand Oaks, CA, USA, 2009; ISBN 978-1-4129-6099-1.

94. Voss, C.; Tsikriktsis, N.; Frohlich, M. Case Research in Operations Management. Int. J. Oper. Prod. Manag. 2002, 22, 195-219. [CrossRef]

95. Koulikoff-Souviron, M.; Harrison, A. Using Case Study Methods in Researching Supply Chains. In Research Methodologies in Supply Chain Management; Physica-Verlag HD: Heidelberg, Germany, 2005; pp. 267-282. ISBN 978-3-7908-1583-2.

96. Seuring, S.; Reiner, M.M.G.; Kotzab, H. Research Methodologies in Supply Chain Management; Kotzab, H., Westhaus, M., Eds.; Physica-Verlag HD: Heidelberg, Germany, 2005; pp. 235-250. ISBN 978-3-7908-1583-2.

97. Zorzini, M.; Hendry, L.C.; Huq, F.A.; Stevenson, M. Socially Responsible Sourcing: Reviewing the Literature and Its Use of Theory. Int. J. Oper. Prod. Manag. 2015, 35, 60. [CrossRef]

98. Almutairi, A.F.; Gardner, G.E.; McCarthy, A. Practical Guidance for the Use of a Pattern-Matching Technique in Case-Study Research: A Case Presentation. Nurs Health Sci. 2014, 16, 239-244. [CrossRef]

99. Seuring, S. Case Study Research in Supply Chains-an Outline and Three Examples. In Research Methodologies in Supply Chain Management; Physica-Verlag HD: Heidelberg, Germany, 2005; pp. 235-250.

100. Seuring, S. Assessing the Rigor of Case Study Research in Supply Chain Management. Supply Chain Manag. 2008, 13, 128-137. [CrossRef]

101. World Trade Organization. Trade Statistics—World Trade Statistical Review 2018; World Trade Organization: Geneva, Switzerland, 2018.

102. Fair Wear Foundation. Fair Wear Foundation-Country Study Vietnam 2015. Available online: https://api.fairwear.org/wpcontent/uploads/2011/12/Country-Study-Vietnam-FINAL_web.pdf (accessed on 12 November 2018).

103. Fair Wear Foundation. Fair Wear Foundation-Country Study Indonesia 2018. Available online: https://api.fairwear.org/wpcontent/uploads / 2017/03/Indonesia-2016-Country-Study.pdf (accessed on 2 November 2018).

104. McCarthy, T.M.; Golicic, S.L. A proposal for case study methodology in supply chain integration research. In Research Methodologies in Supply Chain Management; Physica-Verlag HD: Heidelberg, Germany, 2005; pp. 251-266.

105. Kuckartz, U. Qualitative Text Analysis: A Guide to Methods, Practice E Using Software; SAGE Publications: Los Angeles, CA, USA, 2014; ISBN 978-1-4462-6774-5.

106. Eisenhardt, K.M. Building Theories from Case Study Research. Acad. Manag. Rev. 1989, 14, 532-550. [CrossRef]

107. Duriau, V.J.; Reger, R.K.; Pfarrer, M.D. A Content Analysis of the Content Analysis Literature in Organization Studies: Research Themes, Data Sources, and Methodological Refinements. Organ. Res. Methods 2007, 10, 5-34. [CrossRef]

108. Oelze, N. Sustainable Supply Chain Management Implementation-Enablers and Barriers in the Textile Industry. Sustainability 2017, 9, 1435. [CrossRef]

109. Baskaran, V.; Nachiappan, S.; Rahman, S. Indian Textile Suppliers' Sustainability Evaluation Using the Grey Approach. Int. J. Prod. Econ. 2012, 135, 647-658. [CrossRef]

110. Jiang, B. The Effects of Interorganizational Governance on Supplier's Compliance with SCC: An Empirical Examination of Compliant and Non-Compliant Suppliers. J. Oper. Manag. 2009, 27, 267-280. [CrossRef]

111. Bhaduri, G.; Ha-Brookshire, J.E. Do Transparent Business Practices Pay? Exploration of Transparency and Consumer Purchase Intention. Cloth. Text. Res. J. 2011, 29, 135-150. [CrossRef]

112. Short, J.L.; Toffel, M.W.; Hugill, A.R. Monitoring Global Supply Chains. Strateg. Manag. J. 2016, 37, 1878-1897. [CrossRef]

113. SOMO. Fact Sheet: Hidden Subcontracting in the Garment Industry. Available online: https://www.somo.nl/fact-sheet-hiddensubcontracting-in-the-garment-industry / (accessed on 20 December 2018).

114. Grimm, J.H. Ensuring Sub-Suppliers' Compliance with Corporate Sustainability Standards in Supply Chains. In Supply Management Research; Springer: Wiesbaden, Germany, 2016; pp. 37-57. ISBN 978-3-658-08808-8.

115. Christopher, M.; Lowson, R.; Peck, H. Creating Agile Supply Chains in the Fashion Industry. Int. J. Retail Distrib. Manag. 2004, 32, 367-376. [CrossRef]

116. Hoejmose, S.U.; Adrien-Kirby, A.J. Socially and Environmentally Responsible Procurement: A Literature Review and Future Research Agenda of a Managerial Issue in the 21st Century. J. Purch. Supply Manag. 2012, 18, 232-242. [CrossRef]

117. Dickson, M.A.; Eckman, M. Social Responsibility: The Concept as Defined by Apparel and Textile Scholars. Cloth. Text. Res. J. 2006, 24, 178-191. [CrossRef]

118. The State of Fashion 2019. Available online: https://www.businessoffashion.com/articles/luxury/the-state-of-fashion-2019 (accessed on 26 January 2021).

119. Vogue Business. The New Decentralised Fashion Calendar. Available online: https://www.voguebusiness.com/fashion/thenew-decentralised-fashion-calendar (accessed on 27 January 2021).

120. Maaß, D.; Spruit, M.; de Waal, P. Improving Short-Term Demand Forecasting for Short-Lifecycle Consumer Products with Data Mining Techniques. Decis. Anal. 2014, 1, 4. [CrossRef] 
121. Ren, S.; Patrick Hui, C.; Jason Choi, T. AI-Based Fashion Sales Forecasting Methods in Big Data Era. In Artificial Intelligence for Fashion Industry in the Big Data Era; Thomassey, S., Zeng, X., Eds.; Springer: Singapore, 2018; pp. 9-26, ISBN 9789811300806.

122. Locke, R.; Amengual, M.; Mangla, A. Virtue out of Necessity? Compliance, Commitment, and the Improvement of Labor Conditions in Global Supply Chains. Politics Soc. 2009, 37, 319. [CrossRef]

123. Clean Clothes Campaign. Indonesia Factsheet February 2015. Available online: https://cleanclothes.org/file-repository/ resources-publications-factsheets-indonesia-factsheet-2-2015.pdf/view (accessed on 13 October 2019).

124. Fair Labor Association. Toward Fair Compensation in Vietnam: Insights on Reaching a Living Wage. Available online: https: //www.fairlabor.org/report/toward-fair-compensation-vietnam-insights-reaching-living-wage (accessed on 13 October 2019). 